\title{
The Early Miocene residual flysch basin at the front of the Central Western Carpathians and its palaeogeographic implications (Magura Nappe, Poland)
}

\author{
Marta OSZCZYPKO-CLOWES ${ }^{1, ~ *}$, Nestor OSZCZYPKO ${ }^{1}$, Anna PIECUCH $^{1}$, Jan SOTAK ${ }^{2,3}$ \\ and Józef BORATYN ${ }^{4}$
}

\footnotetext{
1 Jagiellonian University, Institute of Geological Sciences, Gronostajowa 3a, 30-387 Kraków, Poland

2 Slovak Academy of Sciences, Earth Science Institute, Ďumbierska, 97411 Banska Bystrica, Slovakia

3 KU Ružomberok, Department of Geography, Faculty of Education, Hrabovská cesta 1, 03401 Ružomberok, Slovakia

4 Przedsiębiorstwo Geologiczne S.A. w Krakowie, Kijowska 16A, 30-079 Kraków, Poland
}

\begin{abstract}
Oszczypko-Clowes, M., Oszczypko, N., Piecuch, A., Sotak, J., Boratyn, J., 2018. The Early Miocene residual flysch basin at the front of the Central Western Carpathians and its palaeogeographic implications (Magura Nappe, Poland). Geological Quarterly, 62 (3): 597-619, doi: 10.7306/gq.1425

In the Polish sector of the Magura Nappe, along the front of the Pieniny Klippen Belt, strongly tectonized calcareous flysch up to $1000 \mathrm{~m}$ thick is exposed. Previously these deposits, composed of thin- to thick-bedded flysch, with a packet of Łącko-type marls, have been included into several Paleocene/Eocene formations, e.g., the Szczawnica Formation. This formation contains a poor assemblage of agglutinated foraminifera and a relatively rich assemblage of calcareous nannoplankton, with abundant reworked species. The youngest species give evidence of the NN2 Zone (Lower Miocene). Additionally, in three profiles (Szlachtowa, Knurów and Waksmund) of the Kremna Fm., Early Miocene foraminifera have been recognized. This research documented that during the Burdigalian, at the front of Central Western Carpathians, there still existed a residual marine basin probably up to $100 \mathrm{~km}$ wide. These deposits also contain thick packages of exotic carbonate conglomerates derived from the SE, previously regarded as the Jarmuta Formation.
\end{abstract}

Key words: Outer Carpathians, Magura Nappe, residual flysch basin, Early Miocene, calcareous nannoplankton, palaeogeography.

\section{INTRODUCTION}

Since the second half of the last century, there has been a dominant view that the closure of sedimentation in the Magura Paleogene Basin progressed gradually from the Middle Eocene in the Krynica facies zone, in the south, to the Early Oligocene in the Siary facies zone in the north (Sikora and Żytko,1960; Węcławik, 1969; Sikora, 1970; Książkiewicz, 1972, 1977; Birkenmajer and Oszczypko, 1989). This point of the view has been partially modified following the discovery of the Oligocene Malcov Formation (Fm.) above the Magura Sandstone Fm. in the Nowy Sącz and Nowy Targ areas by Oszczypko (1973) and Cieszkowski and Olszewska (1986), respectively. Later, some of these strata were considered by Cieszkowski $(1992,1995)$ as younger marine "molasse" formations of Badenian/Sarmatian age.

At the turn of the last century Oligocene/Miocene flysch deposits were discovered in several places within the Magura Nappe of the Polish and Slovak sectors of the Outer Western

\footnotetext{
* Corresponding author, e-mail: m.oszczypko-clowes@uj.edu.pl
}

Received: September 28, 2017; accepted: April 4, 2018; first published online: August 24, 2018
Carpathians (Oszczypko et al., 1999, 2005a; Oszczypko and Oszczypko-Clowes, 2002; Matašovsky and Andreyeva-Grigorovich, 2002). In subsequent publications (Oszczypko and Oszczypko-Clowes, 2010, 2014) these Oligocene/Miocene deposits have been described as the Kremna Fm. at Stara L'ubovňa (Slovakia) and in the Małe (Little) Pieniny Mts. (Poland). Farther to the east these deposits were recognized by us at the front of the Pieniny Klippen Belt (PKB), at the Obrućne and Dubne localities (Smreczek Stream, right tributary of the Poprad River). This study focuses on the area between Jaworki (E) and Nowy Targ (W), as crucial the understanding the relationship between the Magura Nappe, the PKB and the Central Western Carpathians (CWC). Keeping this in mind we re-evaluate existing as well as new geological and biostratigraphical data of the Oligocene/Miocene deposits at the front of the PKB. This is important for better understanding of the palaeogeography and relationships between the CWC, PKB and Magura Nappe before the Early/Middle Miocene shortening of the Outer Western Carpathians (OWC).

\section{PREVIOUS WORK}

In the Polish Outer Carpathians the Upper Eocene/Oligocene deposits of the Magura Succession were first recognized by Oszczypko (1973), at the southern margin of the Nowy Sącz 
Basin (Nowy Sacz 1 borehole), and in the Zawada and Biegonice sections of the Rača facies zone (Figs. 1, 2 and 3). These deposits, located at the top of the Upper Eocene Magura Sandstone Fm., were regarded as the Malcov Formation (Książkiewicz and Leško, 1959; Leško and Samuel, 1968). In samples from the Malcov Formation, Blaicher (in Oszczypko, 1973) recognized three different age assemblages (benthic and planktonic), albeit intermixed, containing Early/Middle Eocene; Late Eocene/Oligocene and Oligocene species. The youngest Oligocene foraminifera were considered as autochthonous, and the two other assemblages as reworked.

The Biegonice and Zawada sections have been re-examined by Oszczypko et al. (1999). These studies documented the presence of Early Miocene foraminifera (N5) and calcareous nannoplankton (NN1-3) in deposits assigned to the Middle Eocene, as the Łącko Marls. Finally all these marly deposits were included into the Zawada Formation (Oszczypko et al., 1999; Oszczypko and Oszczypko-Clowes, 2002).

Other young deposits (Upper Eocene/Oligocene) of the Magura Succession have been recognized as the Malcov Formation (Cieszkowski and Olszewska, 1986), in several sections near Nowy Targ and close to the PKB (Figs. 1 and 2). In these sections, the thick-bedded Magura-type sandstones with intercalations of grey marly claystones, were previously regarded as the Inoceramian beds (Cenomanian-Turonian - Halicki, 1959; Turonian-Maastrichtian-Danian - Watycha, 1963).

A few years later, the Early Miocene flysch of the Magura Succession was recognized, in the Nowy Targ 1 borehole (Paul and Poprawa, 1992), close to northern boundary of the PKB. More or less simultaneously, in similar deposits (thick-bedded sandstones) Cieszkowski $(1992,1995)$ and Cieszkowski et al. (1993) described the flysch deposits of the Stare Bystre and Rogoźnik sections (Podhale region) which were considered to be the youngest Middle Miocene (Langhian-Serravalian) deposits of the Magura Succession. Recently the age of the Stare Bystre deposits was re-evaluated to be of Early Miocene age (see the discussion in Kaczmarek et al., 2016).

There has been an interesting evolution of views on the age of the youngest deposits of the Magura Nappe in Eastern Slovakia. This began with the discovery by Matašovsky and Andreyeva-Grigorovich (2002) of the Upper Oligocene/Lower Miocene deposits of the Magura Nappe in the Peri-PKB zone near Humenné. Previosly these deposits were regarded to as of Eocene age. Towards the west, near Stara L'ubovňa, in a similar tectonic postion (Peri-PKB zone), there are deposits described by Uhlig (1890a, b, 1903) as the "Nördliche Grenze Flysch Zone". Horwitz (1935) described these strata as the "Peri- or Inter-Klippen Flysch", later distinguished by Matějka (1959) as the Kremna facies. These beds have also been studied by Stranik and Hanzlikova (1968) as the Paleocene/Eocene sandy-conglomeratic calcareous flysch, 1200-1600 m thick, with intercalations of grey-greenish claystones and siltstones.

Many years later these deposits were defined by Oszczypko et al. (2005a) as the Kremna Formation, being the youngest Oligocene-Lower Miocene member of the Magura Succession in the Peri-PKB zone, different from the Malcov Fm. Calcareous nannoplankon studies of the Kremna Fm. showed a predominance $(50 \%)$ of redeposited species, mainly Middle-Late Eocene, while the youngest species identified belong to the Early Miocene (NN1 and NN2 zones, Oszczypko et al., 2005a). The Kremna Fm. is regarded as an equivalent of the Zawada and Stare Bystre formations in the Nowy Sącz and Podhale areas. Recently the Kremna Fm. has been recognized in the Krynica facies zone of the Muszyna and Jaworki areas (Oszczypko and Oszczypko-Clowes, 2010) as well in the "Magura Autochthonous Paleogene" in tectonic windows in the
PKB (Oszczypko and Oszczypko-Clowes, 2010, 2014). Oligocene-Lower Miocene flysch deposits have also been documented in the Horná Orava region of Western Slovakia (Oszczypko-Clowes et al., 2013).

\section{GEOLOGICAL SETTING}

Our studies mainly focus on the Paleogene deposits of the Magura Nappe (Krynica sub-unit), along the northern margin of the Polish sector of the PKB (Figs. 1, 2 and 3). This area is a morphological depression, several kilometres wide, situated between the Pieniny and Małe (Little) Pieniny Mts. to the south and the Gorce/Beskid Sądecki ranges in the north. The "Nördliche Flysch Zone" (Uhlig, 1890a, b, 1903, 1907) or "Magura flysch (Paleocene/Lower Eocene)" (Horwitz, 1935, 1963), placed beneath the Middle/Upper Eocene (sub-Magura and Magura beds), have been regarded as the oldest deposits of the Magura Succession in the the Gorce and Beskid Sądecki ranges. Based on poorly preserved foraminifera, these are regarded as the oldest deposits in this area, and have been classified into the Ropianka beds (Watycha, 1975; Burtan et al., 1981), an equivalenf of the Inoceramian beds (Upper Cretaceous/Paleocene) of the more external units of the Polish Outer Carpathians. Further studies based on small numbers of agglutinated foraminifers and poorly preserved calcareous nannoplankton (Birkenmajer and Dudziak, 1981; Golonka and Rączkowski, 1981, 1984; Alexandrowicz et al., 1984; Kulka et al., 1987, 1991) led to units of Upper Paleocene-Middle Eocene age being distinghuished. The following Paleocene/Eocene formal lithostratigraphy of the Krynica sub-unit has been proposed by Birkenmajer and Oszczypko (1989): the Szczawnica Formation (Middle/Upper Paleocene), up to $400 \mathrm{~m}$ thick, with the level of the Łącko Marls (up to $50 \mathrm{~m}$ ), followed by the Frydman Fm. (Lower Eocene), up $400 \mathrm{~m}$ thick, and the Magura Sandstone Fm. (Lower/Upper Eocene), overlain by the uppermost Eocene/Lower Oligocene Malcov Fm.

The Magura Fm. is the youngest deposit of the Krynica sub-unit, with the exception of the Malcov Fm., locally occurring near Nowy Sącz (Oszczypko, 1973) and Nowy Targ (Cieszkowski and Olszewska, 1986). The Magura Fm., up to $2000 \mathrm{~m}$ thick (Birkenmajer and Oszczypko,1989; Kulka et al., 1991) is dominated by massive, thick-bedded sandstones, with sporadic intercalations of thin-beddded turbidites. The Magura $\mathrm{Fm}$. is subdivided into three members: the Piwnicza Sandstone Member (PSM), the Mniszek Shale Member (MSM) and the Poprad Sandstone Member (PoSM). This formation is dominated by coarse clastic turbidites, resulting in a scarcity of agglutinated foraminifera and a dominance of reworked calcareous nannoplanton.

In the PSM, there are calcareous nannoplankton belonging to NP15/17 in the Piwniczna area (Oszczypko-Clowes, 2001; Oszczypko and Oszczypko-Clowes, 2010) and NP18-20 in the Muszyna area (Dudziak in Oszczypko et al., 1990). The MSM is represented by variegated shales with Reticulophragmium amplectens which was traditionally regarded as a Middle Eocene form, while now it indicates the Late Eocene (Bindiu et al., 2015).

West of the Poprad River, the MSM has not been confirmed. In this part of the Krynica sub-unit, the position of the MSM is possibly occupied by the Kowaniec beds. These beds, up to $100 \mathrm{~m}$ thick, are composed of thin to medium-bedded turbidites.

In the Polish sector of the Krynica sub-unit, the PoSM has not been precisely dated. By contrast, samples collected from the Ruska Vola section on the Poprad River (Eastern Slovakia), con- 


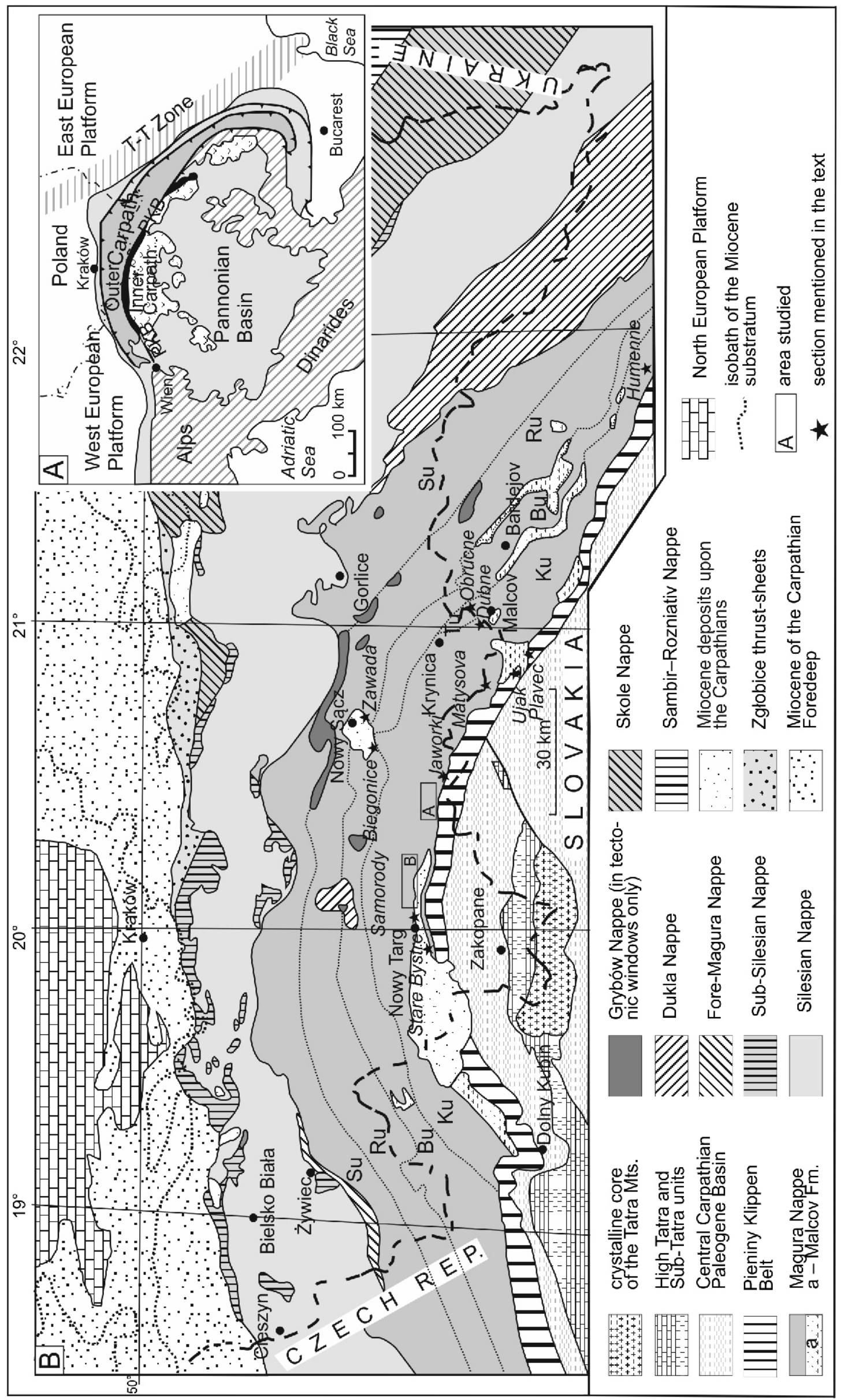

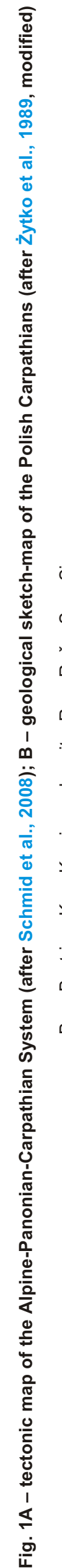




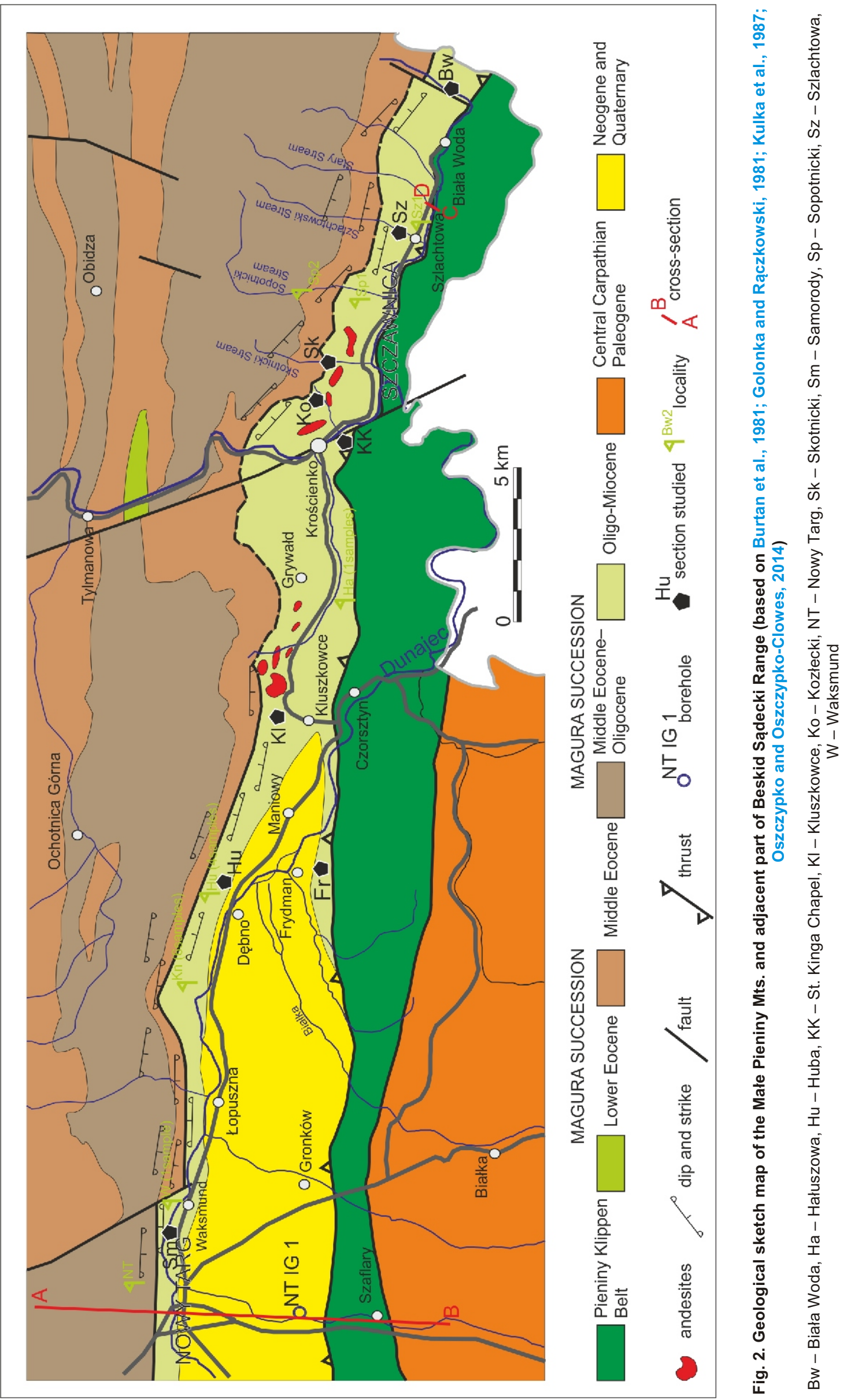




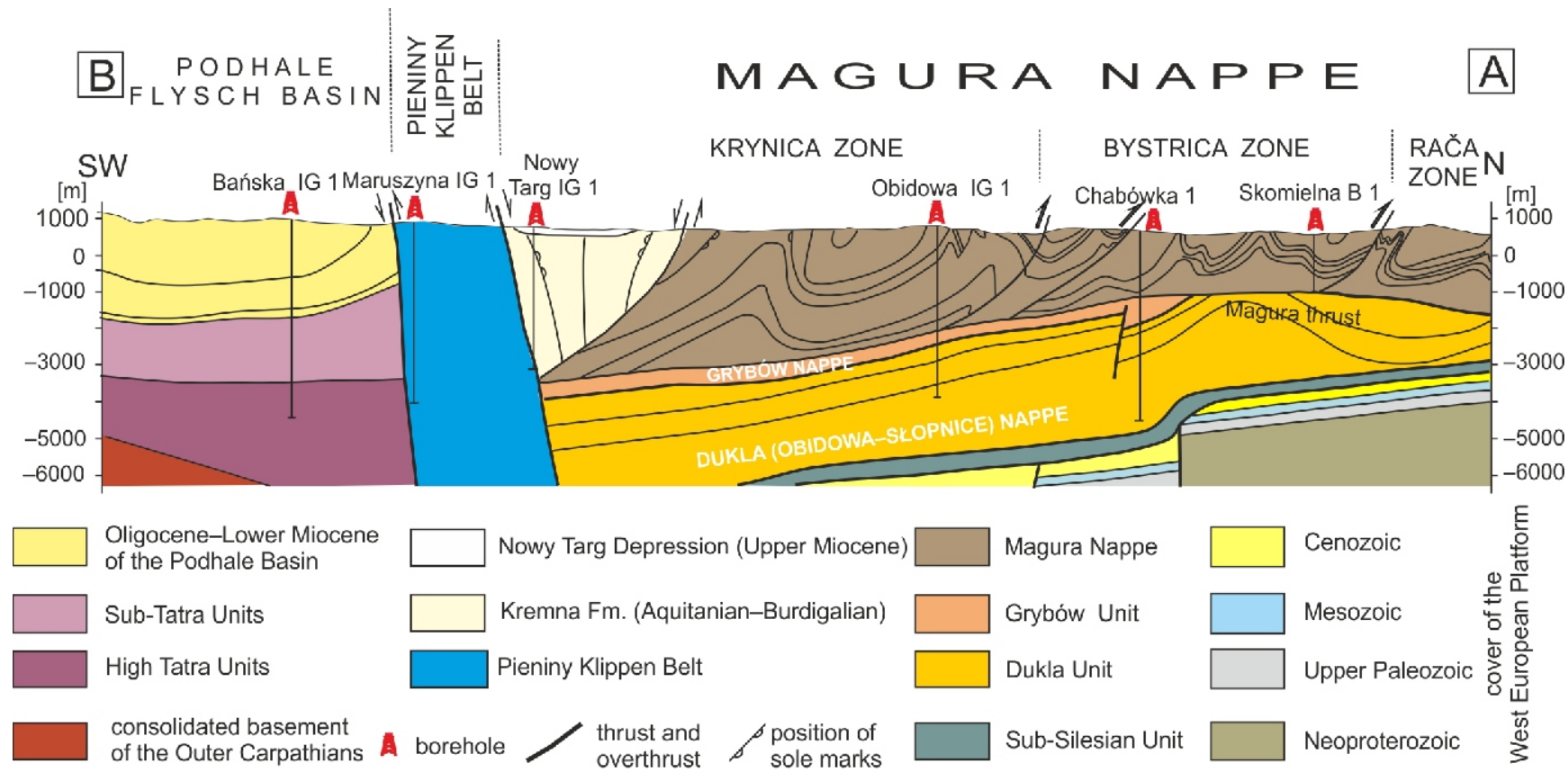

Fig. 3. Geological cross-section Obidowa IG 1-Bańska IG 1 (based on Oszczypko, 1997), modified

tain a well-preserved and moderately abundant nannofossil assemblage belonging to the NP25 and NN1 zones, followed by the Kremna Fm. (NN1-2; Oszczypko-Clowes in Oszczypko et al., 2005a). The same age was determined in samples collected in the upper part of the Homole Gorge and Biała Woda sections of the PKB (Oszczypko and Oszczypko-Clowes, 2010, 2014).

\section{METHODOLOGY}

Our current research has been focused on the Polish sector of the Peri-PKB zone, between the Biała Woda Stream in the east (Małe Pieniny Mts.) and the Nowy Targ-Orava Neogene Depression in the west (Figs. 1 and 2). This area linked the already known occurrences of Oligocene/Miocene deposits in the valley of the Poprad River (Oszczypko et al., 2005a; Oszczypko and Oszczypko-Clowes, 2010), the Małe Pieniny Mts. (Oszczypko and Oszczypko-Clowes, 2010, 2014), and near the Nowy Targ area (Cieszkowski and Olszewska, 1986; Cieszkowski, 1992; Paul and Poprawa, 1992; Kaczmarek et al., 2016). Taking into account the poor condition of exposures in this area it has been necessary to use all available natural exposures.

Geological profiling was conducted using traditional methods, but fully linked to satellite navigation (GPS way points WP). The profiling allowed us to establish the stratigraphic succession of beds as well as their lithological and sedimentological character.

In order to establish the age and variability of assemblages in the samples, species of nannoplankton and planktonic foraminifera were determined. Slides for nannofossil determination were prepared using a simple smear slide technique according to Bown and Young (in: Bown, 1998). All samples were analysed with a Nikon-Eclipse E 600 POL, at 1000x magnification using both parallel and crossed polars. Qualitative analyses allowed the age determination. The taxonomic framework applied is based upon Aubry (1984, 1988, 1989, 1990, 1999), Perch-Nielsen (1985) and Bown (1998 and references therein). Biostratigraphy is based on the standard zonation of Martini and
Worsley (1970). However, the marker species for the Lower Miocene zones are absent or very rare at high latitudes. In such cases secondary index species, proposed by Fornaciari and Rio (1996), Fornaciari et al. (1996) and Young (1998), had to be applied.

In addition, a quantitative analysis was performed for samples from the Huba section. Quantitative analyses involved using counts of 300 specimens in random fields of view for selected samples, in order to ascertain the percentage content of reworked and autochthonous species. According to Thierstein et al. (1977), at the 95\% confidence level, 300-specimen counts ensure the presence of a taxon whose relative abundance was $1 \%$ in the total population. The palaeoecological analyses were performed on autochthonous assemblages. The percentages were taken literally.

Nannofossil preservation was visually estimated using the criteria proposed by Roth and Thierstein (1972). The categories are based on the degree of etching and/or calcite overgrowth observed during light microscopy and are: VP - very poor, etching and mechanical damage is very intensive, specimens mostly in fragments; $\mathrm{P}$ - poor, severe dissolution, fragmentation and/or overgrowth; the specific identification of specimens is difficult; $\mathrm{M}$ - moderate, etching or mechanical damage is apparent but most specimens are easily identifiable; G - good, little dissolution and/or overgrowth; diagnostic characteristics are preserved, the specimens could be identified to species level without any trouble.

Estimate of the nannofossil abundance for individual samples was established using the following criteria: $\mathrm{VH}$ - very high (>20 specimens per view field), $\mathrm{H}-$ high (10-20 specimens per view field), $\mathrm{M}-$ moderate (5-10 specimens per view field), $\mathrm{L}-$ low (1-5 specimens per view field), VL - very low ( $<5$ specimens per 5 view fields).

Aditionally, in the Stary Stream in Szlachtowa and Waksmund sections, the determination of calcareous nannoplankton was supplemented by the analysis of small foraminifera (Figs. 1 and 2). 


\section{RESULTS}

\section{SECTIONS STUDIED}

Studies carried out in Eastern Slovakia near Stara L'ubovňa (Oszczypko et al., 2005a) have clearly demonstrated that the Poprad Sandstone Mb. of the Magura Fm. (NP25/NN1) is overlain by flysch of the Kremna Fm. (NN1/NN2). This sequence has been documented in the Matyšova section (N49 18.864 E20 ${ }^{\circ} 46.513^{\prime}, 542 \mathrm{~m}$ a.s.I.) and at Sedlo Vabec (N49 $20.585^{\prime}$ E20 40.513 .658 ', $750 \mathrm{~m}$ a.s.I.). On the Polish side, the stratigraphic succession of the Kremna Fm. above the Poprad Sandstone Mb. has only been documented in the Biała Woda Valley. Farther to the west, in the vicinity of Nowy Targ, this contact is not visible. The interpretation of existing geological maps (Watycha, 1975; Burtan et al., 1981; Kulka et al., 1991) and our field observations suggest a tectonic contact. Unfortunately, these maps dating back to the last century are largely outdated.
The discovery of the Kremna Fm. (Oligocene/Lower Miocene), previously described and assigned to the Szczawnica Fm. (Paleocene/Lower Eocene), is of paramount importance.

Biała Woda Stream section (WP 77 and 506; N49 $\left.23.826^{\prime} \quad \mathrm{E}^{\circ} 0^{\circ} 35.307^{\prime}\right)$. The profile studied, $2 \mathrm{~km}$ long (Fig. 4), is located in the upper section of Biała Woda Creek. The results from this section have already been published (Oszczypko and Oszczypko-Clowes, 2010, 2014). However, in the area studied, on the Polish side, this is the only profile documenting the stratigraphic succession of the Kremna Fm. above the PoSM. The profile displays SW-dipping (Fig. 4), deposits, in normal position, of the Lower Miocene Kremna Fm. (Oszczypko and Oszczypko-Clowes, 2010, 2014), composed of dark grey laminated marly mudstones with the Dendritus ichnofacies, with sporadic intercalations of thin-bedded, turbiditic sandstones. These beds were previously regarded (Birkenmajer, 1979; Golonka and Rączkowski, 1984) as the Szczawnica Fm. (Paleocene/Lower Eocene). Towards the south, the Kremna Fm. has tectonic contact with the PKB (Fig. 4B).
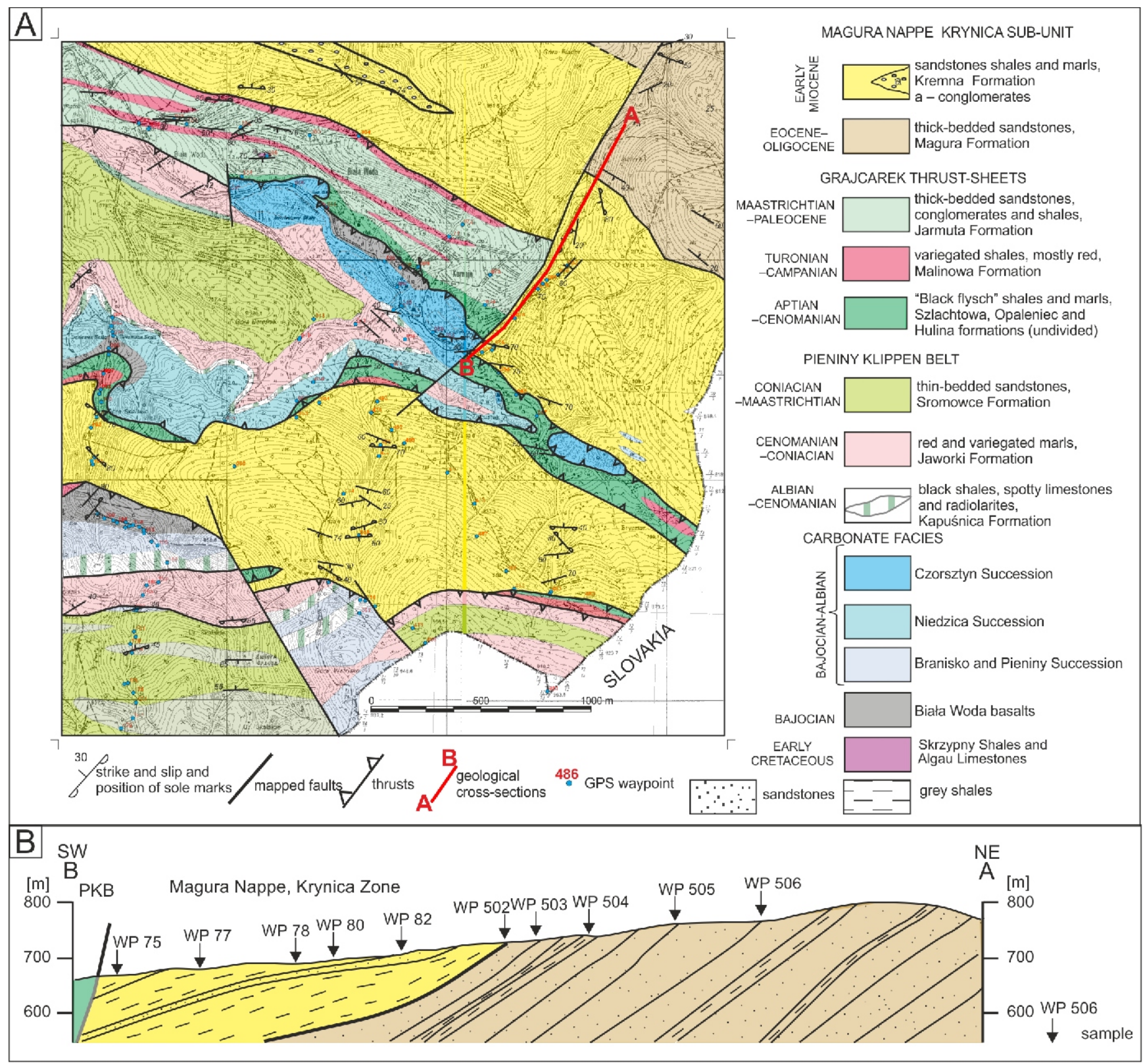

Fig. 4A - geological map of the Biała Woda area (after Oszczypko and Oszczypko-Clowes, 2014); B - cross-section 
Stary Stream in Szlachtowa; (WP 329-337: N49 ${ }^{\circ} 24.757$ E20 ${ }^{\circ} 32.952^{\prime}$ to WP 279: N49 $24.950^{\prime}$ E20 $\left.{ }^{\circ} 33.169^{\prime}\right)$. This section displays the tectonic contact of the Grajcarek Unit (Fig. 5) with the Kremna Fm. of the Magura Nappe. Here, variegated shales of the Malinowa Fm. (Turonian-Campanian) of the Grajcarek Unit are thrust, in overturned position, on the SSW-dipping, in normal position, deposits of the Kremna Formation. This formation is composed of dark grey marly mudstones and thick-bedded (1-3 m), Łącko-type marls, with intercalations of thick-bedded (0.4-1.0 m) sandstones (Fig. 6). The marls are massive with delicate horizontal lamination.

Skotnicki Stream section near Szczawnica (WP 491: N49 ${ }^{\circ} 23.594^{\prime}$ E20 $34.983^{\prime}$ to WP 499: N49 $24^{\circ} 041^{\prime}$ $\left.\mathbf{E}^{\circ}{ }^{\circ} 34.903^{\prime}\right)$. The geological map of Kulka et al. (1987) shows the following interpretation of the geological structure of the Skotnicki Stream: the Szczawnica Beds (Paleocene/Eocene) with andesite dikes in the lower part of the creek pass upwards into the Eocene sequence of the Magura Fm., represented by the PSM followed by the Kowaniec Beds and the PoSM of the Magura Fm. Taking into account that the former Szczawnica Fm. (Paleocene/Eocene) now belongs to the Kremna Fm. (Oligocene-Miocene), our interpretation of this section is different.

The first exposures of the Kremna Fm., visible above the Pitoniakówka mineral water spring (Fig. 7A), are represented by thin- to medium-bedded fine-grained calcareous sandstones, accompanied by dark grey marly mudstones and shales. These strongly brecciated beds, dipping sub-vertically to the north, are in overturned position. Going up the stream, after $\sim 150 \mathrm{~m}$, the right inlet shows large blocks of Neogene andesites (Fig. 7A). After a few tens of metres, exposure disappears, and over a distance of $\sim 150 \mathrm{~m}$ there are coluvia of an active landslide on the right slope of the valley. This landslide covers the contact between the Kremna and the Magura formations.

After the break in exposure, above a bifurcation in the stream, we found in the right inflow (Biały) the first exposure (WP 491, Fig. 7A, B), represented by $5 \mathrm{~m}$ thick grey shales with an intercalation of thick-bedded sanstone $(1.5 \mathrm{~m})$. Uphill, these strata dip to the south (190/60), in overturned position. This type of deposit, up $50 \mathrm{~m}$ thick, can be correlated with the Kowaniec beds the Magura Fm. Higher up in the section, dark-grey thin bedded turbidites are exposed, with a dominance of marly mudstones, at least $25 \mathrm{~m}$ thick (Figs. 7C and 8). These thin-bedded turbidites continue to be south-dipping and overturned. This succession can probably be correlated with the Kowaniec Member (Middle to Upper Eocene, see Kulka et al., 1987, 1991). Above WP 495 to WP 496 the Kowaniec Mb. is followed by thick- to very thick-bedded sandstones of the PoSM of the Magura Fm. (Figs. 7 and 8). The Kowaniec Beds in the Skotnicki Stream are well-known as a correlative horizon (formerly the sub-Magura Beds, see Burtan at al., 1981; Birkenmajer and Oszczypko, 1989). On the southern slope of the Gorce and Besid Sądecki ranges, the Kowaniec Member marks the boundary between the PSM and PoSM of the Magura Fm. In the Skotnicki Stream the north-dipping (in overturned position) Kremna Fm. (Oligocene/Miocene) contacts with the south-dipping (in overturned position) Magura Fm. (Middle/Upper Eocene), along a reverse fault. A similar boundary between the Magura Fm. and Kremna Fm. was documented (Figs. 2 and 3) on the right slope of the Grajcarek Valley, between Szczawnica and Biała Woda (see Oszczypko and Oszczypko-Clowes, 2014).

\section{KROŚCIENKO ON THE DUNAJEC RIVER}

Kozłecki Stream section (WP501-504; N49 ${ }^{\circ} 26.453^{\prime}$ E20'26.753'; Fig. 9). The section studied is located in the lower run of the Kozłecki Stream, at the right confluence of the Dunajec River (Fig. 2). This $\sim 100 \mathrm{~m}$ long section is composed of medium-bedded $(20-30 \mathrm{~cm})$, fine to very fine-grained sandstones with an intercalation of dark grey marly shales (Fig. 8). The flute marks display axes of palaeotransport of $20^{\circ}$ (NNE)-200 (SWS). In previous studies these strata have been regarded as the Szczawnica Formation (Upper Paleocene/Lower Eocene: Birkenmajer and Dudziak, 1981; Alexandrowicz et al., 1984; Kulka et al., 1987, 1991; Golonka and Waśkowska, 2014). Higher up in the section (WP 503-504), on the left bank of the creek, grey shales with a thick bed of exotic conglomerate are exposed. The deposits from Kozłecki Stream can be regarded as the NW prolongation (in the same tectonic position) of the Kremna Formation from Sopotnicki Stream.

Krościenko on the Dunajec River, Chapel St. Kinga section (WP523-528; N49 $25.921^{\prime}$ E20 ${ }^{\circ} 26.322$; Figs. 10 and 11). This section belongs to the Paleogene deposits of the
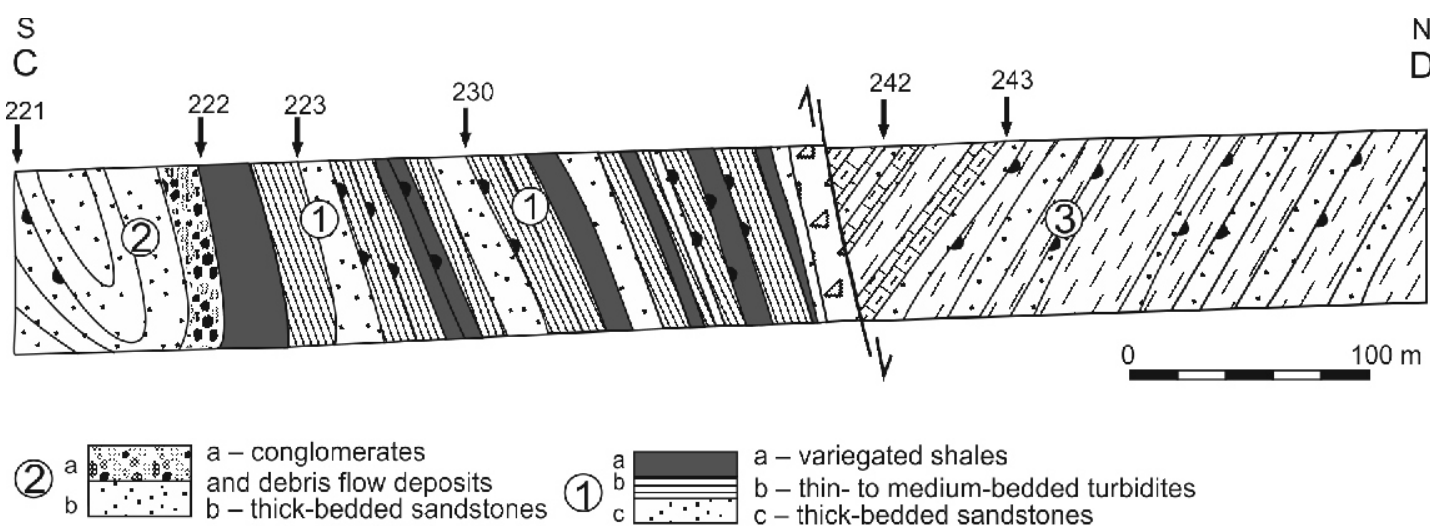

a - variegated shales

$\mathrm{b}$ - thin- to medium-bedded turbidites

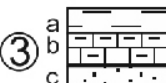

a - grey shales

b - marls

$\mathrm{c}$ - thick-bedded sandstones

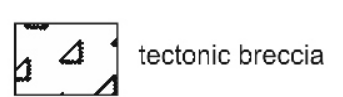

$\underset{\sim}{\sim}$ fault $\stackrel{329}{\downarrow}$ GPS waypoint

Fig. 5. Cross-section through the northern boundary contact zone of the Grajcarek thrust sheets and the Magura Nappe, Stary Stream section (based on Oszczypko and Oszczypko-Clowes, 2014, supplemented) 


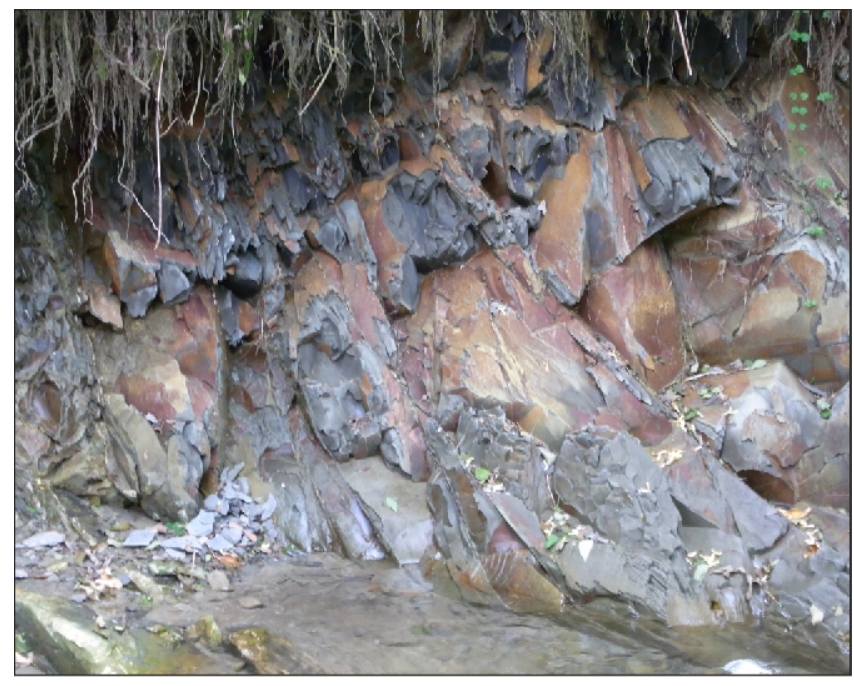

Fig. 6. Thick-bedded marls of the Kremna Fm. from the Stary Stream section at Szlachtowa

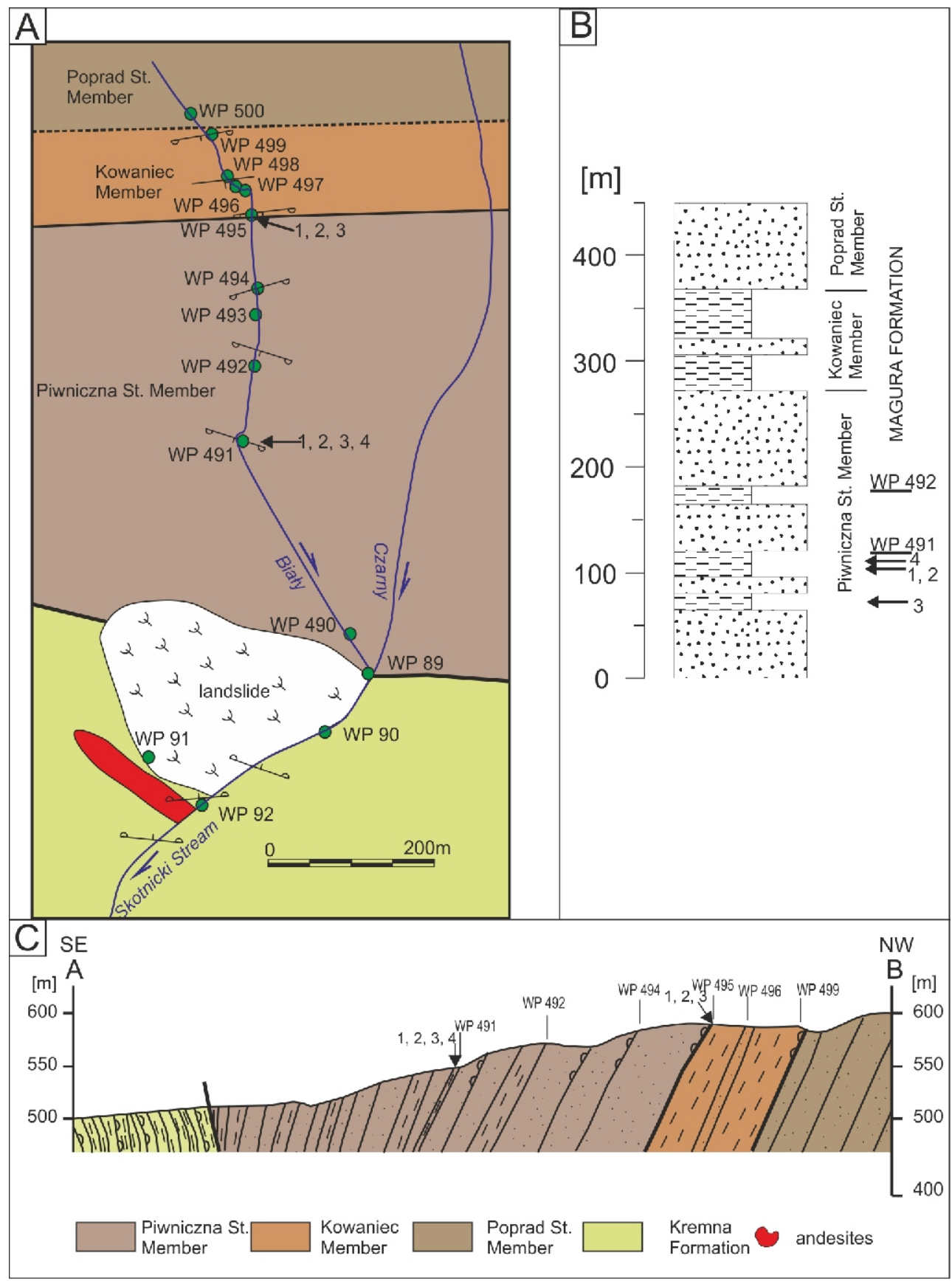

Fig. 7A - geological map, B - lithostratigraphic log of the Skotnicki Stream section, C - cross-section 

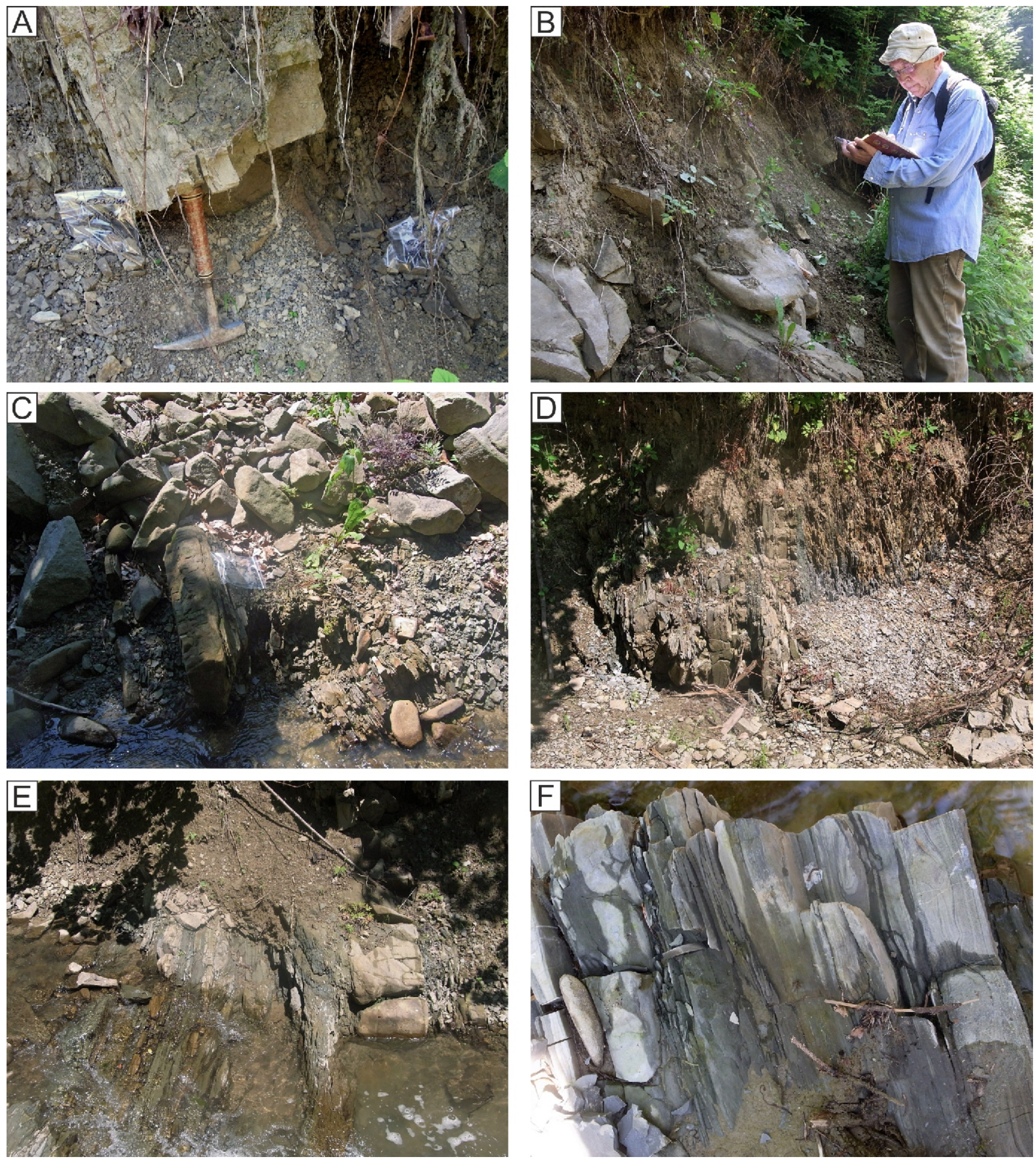

Fig. 8. Typical lithofacies the Skotnicki Stream section at Szczawnica

A - dark marly shales with intercalations of broken, thick-bedded, sandstone in overturned position; B - dark marly shales with intercalations of medium-grained thick-bedded sandstone; $\mathbf{C}$ - debris of fine-grained sandstones; $\mathbf{D}$ - vertical dipping, dark shales with intercalations of very fine-grained sandstones, in vertical position; $\mathbf{E}$ - sub-vertical dipping, dark shales with intercalations of medium-bedded sandstones; F - thick-bedded, laminated fine-grained sandstones with intercalations of dark shales 

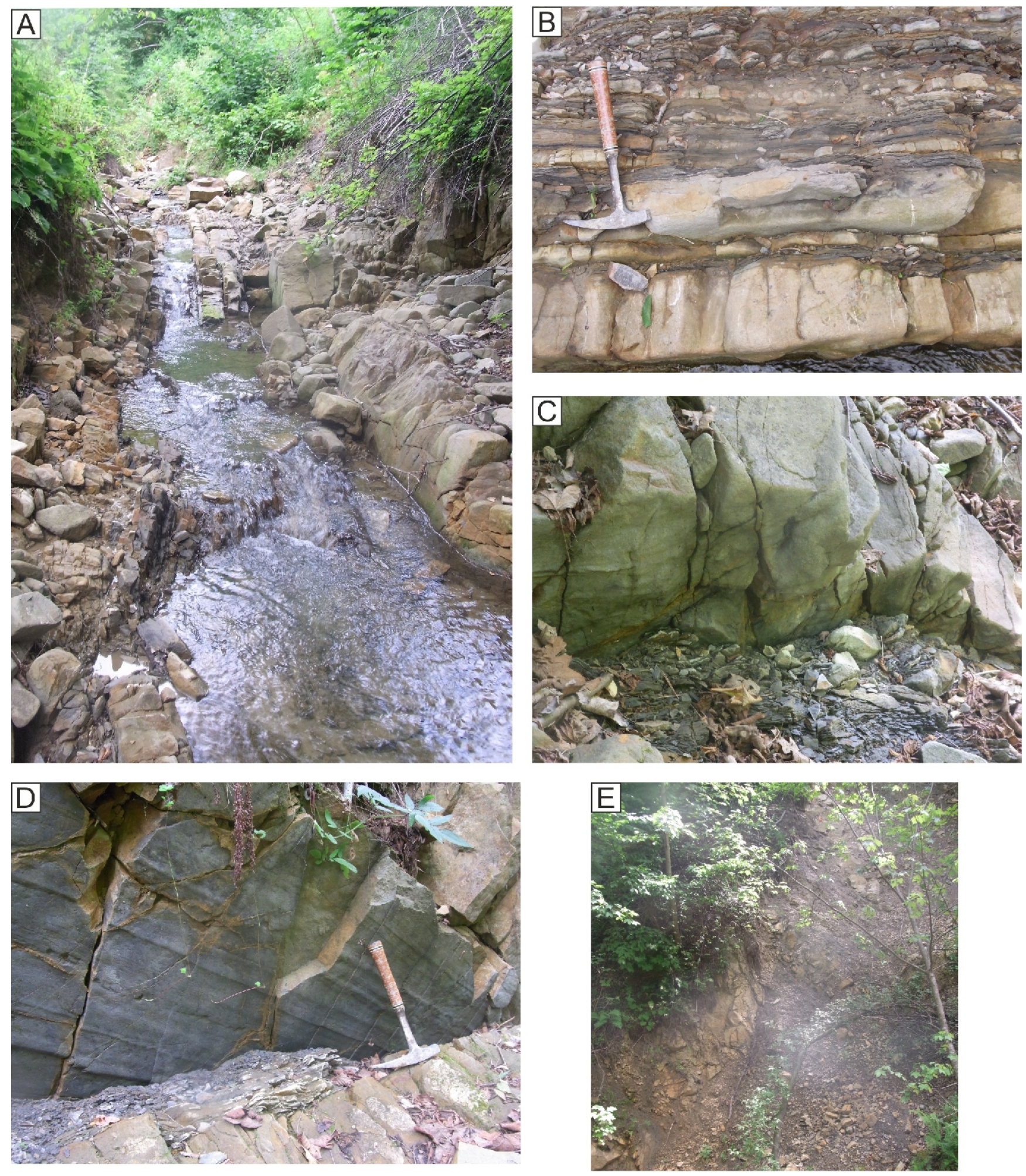

Fig. 9. Typical lithofacies from Kozłecki Stream section

A - vertical dipping, thick-bedded turbiditic sandstones; B - thin and very thin-bedded turbiditic sandstones with thin intercalations of shales, in overturned position; $\mathbf{C}$ - fragment of thick-bedded sandstone incorporated in dark shales; $\mathbf{D}$ - drag flute casts on the basal surface of the thick-bedded sandstone; $\mathbf{E}$ - dark shales with intercalations of the thin-bedded sandstones 


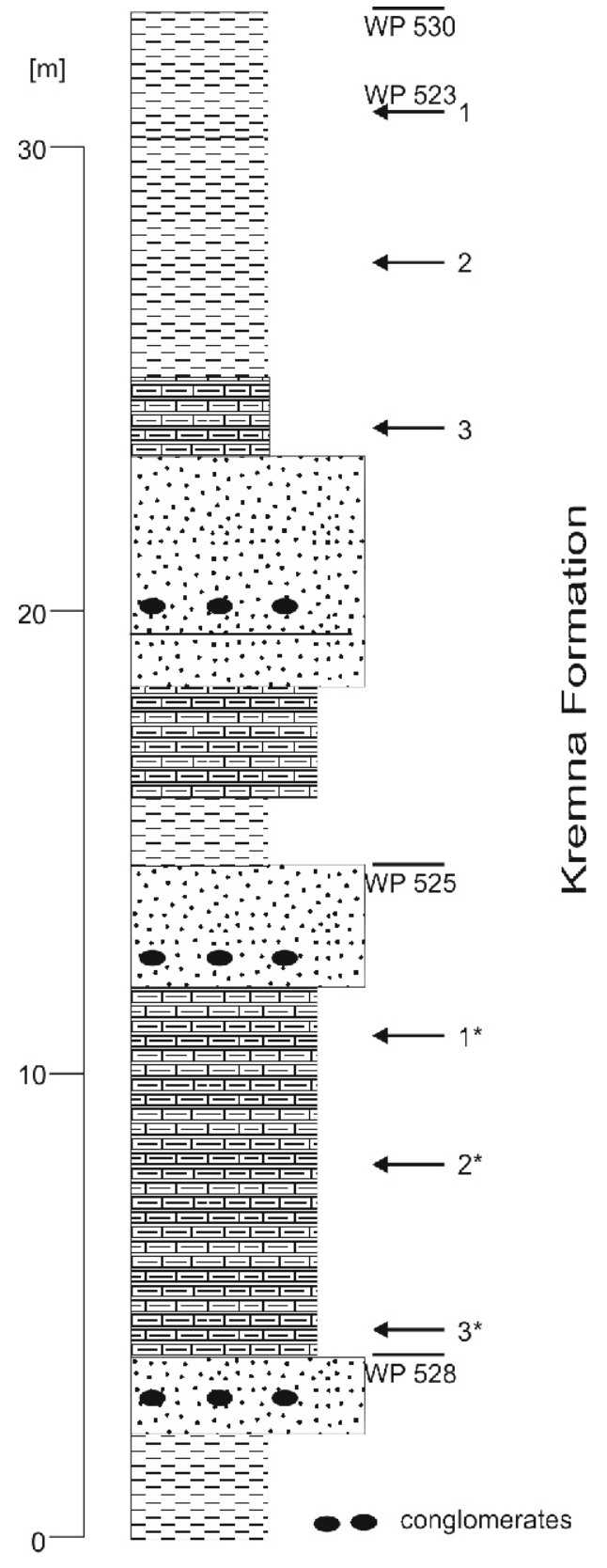

Fig. 10. Lithostratigraphic log of the St. Kinga section

For other explanations see Figure 5

Krynica succession of the Magura Nappe, close to the northern boundary of the PKB. This is a large exposure well-known as the Zawiasy section (Birkenmajer, 1979, 1986; Golonka et al., 2006). According to Birkenmajer $(1979,1986)$ the Zawiasy section belongs to the Jurassic-Lower Cretaceous succession of the Branisko Unit. Here, the PKB and the Magura Nappe contact along a longitudinal reverse fault. According to Golonka et al. (2006) this boundary developed as a major right-lateral strike-slip fault, between the Magura Nappe and the PKB. Recently, Golonka et al. (2015) considered the Zawiasy Klippen to be a big olistolith developed during the Paleocene. Birkenmajer (1986) interpreted that between the Branisko Unit and the Magura Nappe there are wedged fragments of the Grajcarek Unit (Malinowa and Jarmuta formations), now not exposed. The geological profile of the left bank of the Dunajec River, near the Chapel of St. Kinga, was first described by Alexandrowicz et al.
(1966). In this exposure, all deposits of the Magura succession are NW-dipping (Fig. 10), in overturned position $\left(350-340^{\circ} / 15-35^{\circ}\right)$. This $\sim 30 \mathrm{~m}$ thick profile is composed of shales and siltstones with intercalations of thin-beddded laminated sandstones as well as medium- to thick-bedded sandstones with convolutions and clasts of shale balls. The base and top of the profile is composed of Łącko-type marls, $\sim 9 \mathrm{~m}$ and $2.2 \mathrm{~m}$ at the base and the top respectively. The profile studied displays coarsening- and thicking-upwards sequences (Figs. 10 and 11), composed of thick-bedded sandstones (1.8 up to $5.0 \mathrm{~m}$ ). These sandstones are amalgamated and contain clast levels. The sandstone beds are overlain by hard grey-greenish Łacko-type marls, up to $3 \mathrm{~m}$ thick. The marls are followed by dark grey marly mudstones, up to $8 \mathrm{~m}$ thick (Fig. 10). For long, these deposits were regarded as the Szczawnica Fm. of Paleocene/Eocene age; their age was determined first by Alexandrowicz (1966), based on rare benthic and planktonic foraminifers such as Globorotalia marginodentata Sub., and G. cf. crassata Cushman, and subsequently Birkenmajer and Dudziak (1981) included these beds into the upper part of the Szczawnica Formation (Lower Eocene, NP-10/11 Zone). These beds have been regarded as the Zarzecze Formation (Chrustek et al., 2005). Recently, Golonka and Waśkowska (2014) studied foraminifera from this section and determined the age of these deposits as not older than late Ypresian-early Lutetian.

\section{DUNAJEC RIVER WEST OF CZORSZTYN}

Frydman ( $\left.\mathrm{N}^{\circ} 9^{\circ} 26.413 \mathrm{E} 20^{\circ} 14.115\right)$. The section sudied is located along the road from Frydman to Czorsztyn (Fig. 2). In the abandoned quarry WP 657 are exposed thick-bedded sandstones $(0.5-1.5 \mathrm{~m})$ steeply dipping to the south $\left(170 / 70^{\circ}\right.$ in normal position), with an intercalation of thin-bedded, very fine sandstone and grey marly shales (Fig. 12). The thick-bedded sandstones contain muddy clasts and show palaeotransport direction from the east.

Huba $\left(\mathrm{N}^{4} 9^{\circ} 27.889 \mathrm{E} 20^{\circ} 14.599\right)$. This profile is located below the Huba-Maniowy/Czorsztyn road, in a small left tributary of the Czorsztyn Lake (WP 27).

Over a distance of $\sim 170 \mathrm{~m}$, the profile exposes a shale/sandstone succession $\sim 100 \mathrm{~m}$ thick. The succession is sub-vertically dipping to the $\mathrm{N}(360 / 70)$, in overturned position. This succession is composed of medium- to thick-bedded sandstones with intercalations of dark grey marly shales (Fig. 13). The grey hard, medium to thick-bedded sandstones are mainly fine-grained. Locally, the basal parts of the beds are composed of chaotically dispersed quartz and lithoclastic grains, passing upwards into the fine, oblique-laminated sandstone. The laminate surfaces are rich in coalified plant and muscovite detritus. In some places, in the lower and the middle parts of the profile, occur intercalations of the Łącko type marls, up to $2 \mathrm{~m}$ thick. There is an exposure gap in the $80-155 \mathrm{~m}$ interval of the profile. This succession has been distinguished by Watycha (1976) as the Lower Eocene of the Turbacz Beds or the Lower Eocene sub-Magura Beds by Birkenmajer and Dudziak (1981) and Kulka et al. (1991).

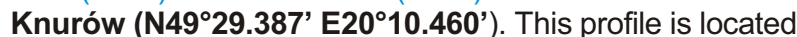
$\sim 4 \mathrm{~km}$ west of locality Huba (Fig. 2). In the left tributary of the Dunajec River Magura-type sandstones are exposed, with intercalations of marly shales. These deposits dip gently to the north and were classified by Burtan et al. (1981) as the Paleocene Ropianka Beds. Later Cieszkowski (1992) defined these strata as the Malcov Formation and Waksmund Beds (Uppermost Eocene-Lower Miocene). 

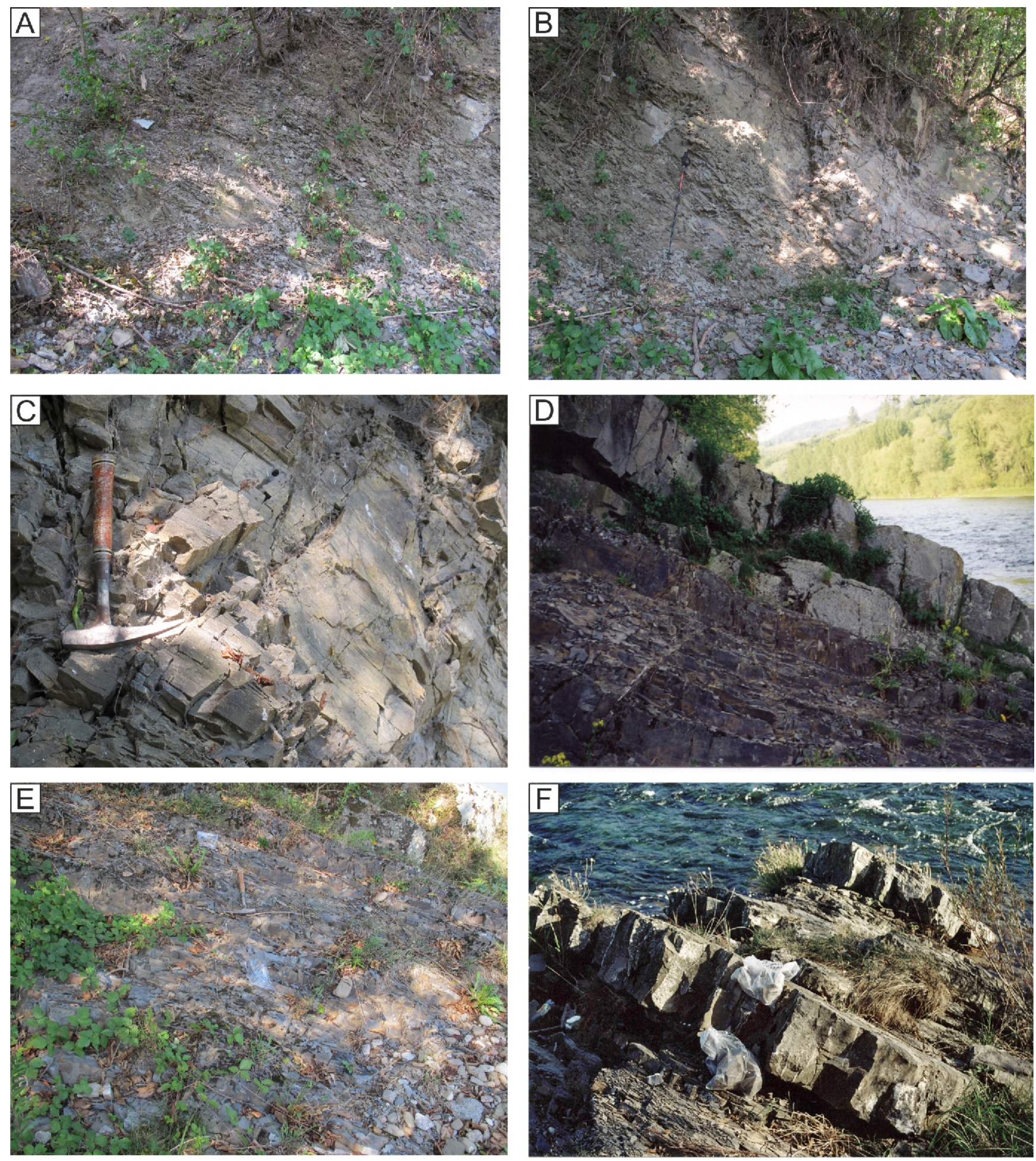

Fig. 11. Typical lithofacies in the St. Kinga section.

A, B - packets of the thin-bedded flysch deposits; C - broken packets of the Łącko type marls; D - overturned, NE dipping sequence of the thick-bedded sandstones, "Kącko Marls" and thin-bedded turbidites; E, F - detail of the Figure 11D 

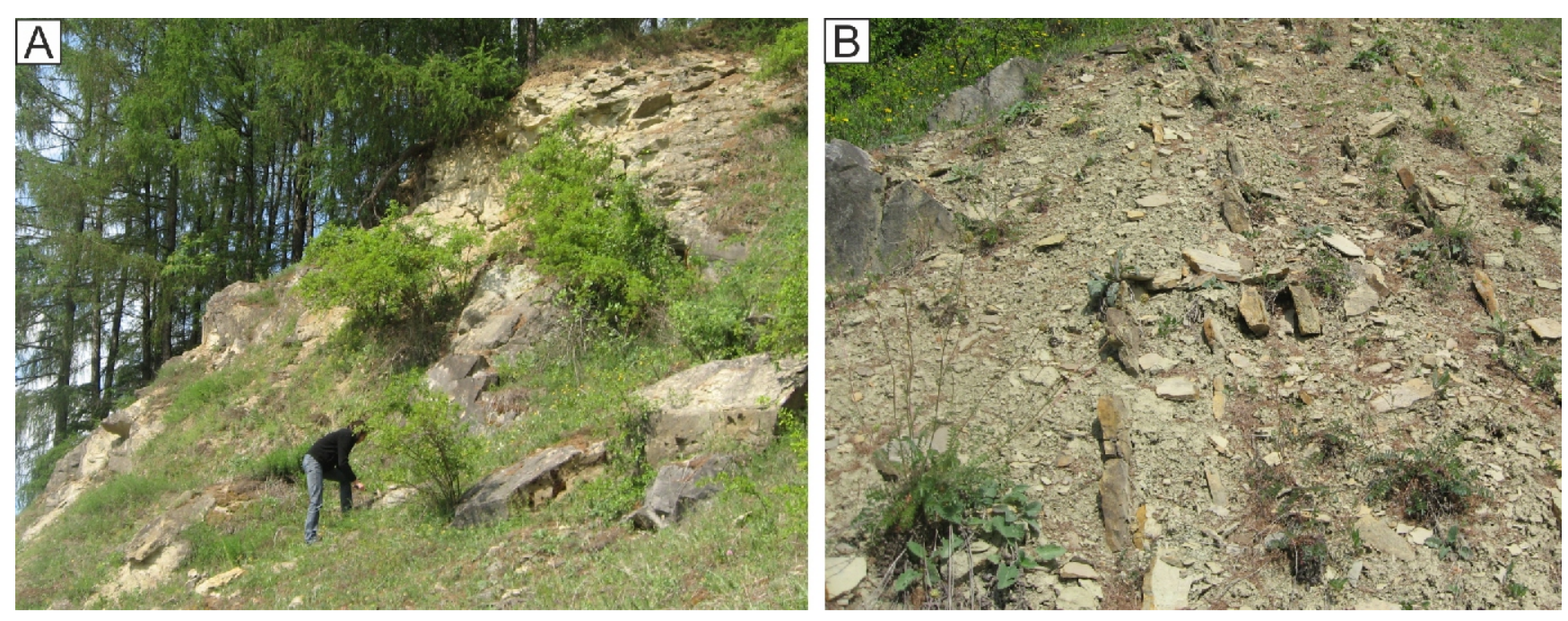

Fig. 12. Very thick-bedded sandstones and marly shales in the Frydman section

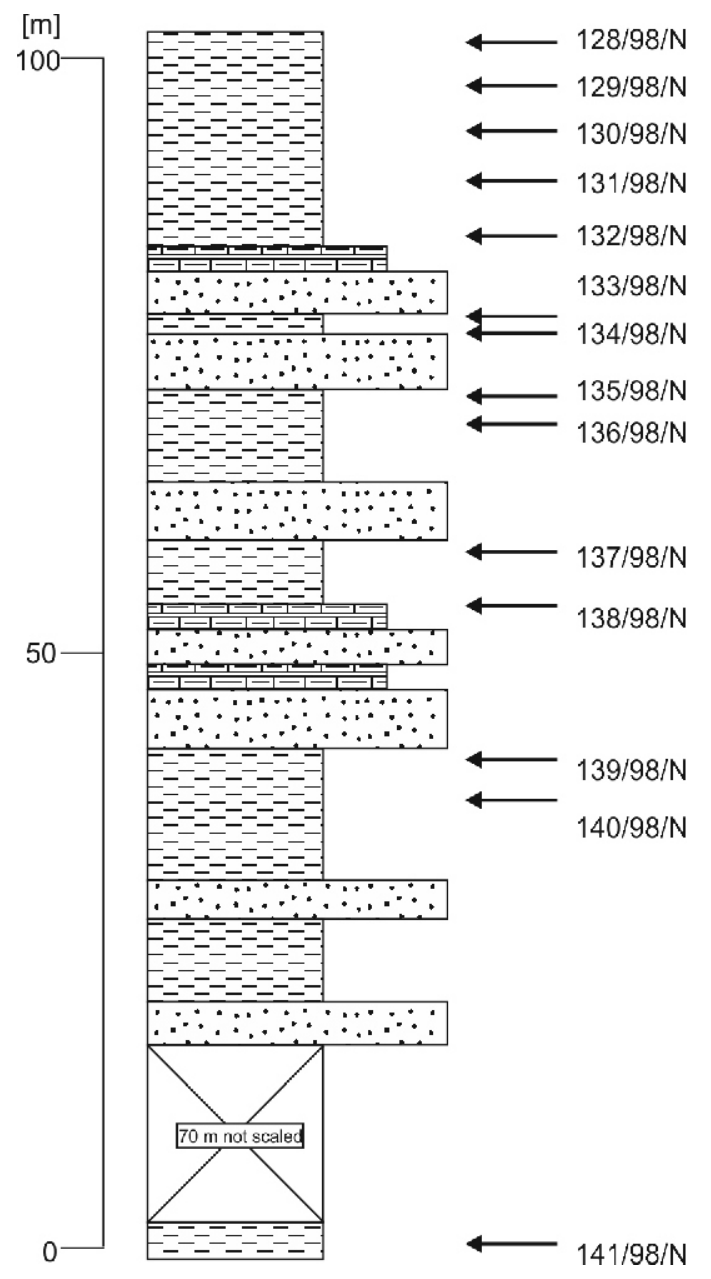

Fig. 13. Lithostratigraphic log of the Huba section

For lithology explanation see Figure 5
Waksmund ( $\left.\mathrm{N}^{\circ} 9^{\circ} 29.418^{\prime} \mathrm{E} 20^{\circ} 04.520^{\prime}\right)$. These exposures are located at Waksmund, $\sim 1.5-2 \mathrm{~km}$ east of Nowy Targ (Fig. 2). Burtan et al. (1981) included these deposits into the Inoceramian-Ropianka Beds (Paleocene). Later (Cieszkowski and Olszewska, 1986) classified them as the Malcov Formation (uppermost Eocene-Oligocene), and Cieszkowski (1992) termed them the Waksmund Beds.

\section{PRESERVATION, SPECIES DIVERSITY AND ABUNDANCE} OF CALCAREOUS NANNOPLANKTON

Considering all the assemblages investigated, the preservation of calcareous nannofossils is moderate $(\mathrm{M})$ or predominantly moderate-to-good (M-G) (Appendices 1 and $2^{*}$ ). Nannofossils show minor etching and minor to moderate overgrowth. The good to moderate preservation of nannofossils indicates that little carbonate dissolution has occurred in these deposits (Fig. 14).

For each sample the ratio between autochthonous and reworked nannofossils was estimated. To distinguish reworked from in-place nannofossils the full stratigraphic ranges of species were used. Individual species older than the youngest assemblage were identified as reworked taxa.

A maximum of 66 species were identified during quantitative and qualitive analyses of the calcareous nannoplankton. However, the abundance pattern as well as the taxonomical diversity varies, not only between sections but also between samples from a particular section.

Skotnicki Stream section. The majority of samples were barren and only four samples contained determinable nannoplankton species. The assemblage is moderately diverse. The most characteristic species are Cyclicargolithus floridanus, Ericsonia formosa, Zygrhabilithus bijugatus, Neococcolithes dubius, Chiasmolithus grandis, Coccolithus pelagicus, Sphenolithus radians, Discoaster deflandrei, D. binodosus and Chiasmolithus solitus.

Kozłecki Stream, Chapel St. Kinga, Huba, Frydman, Knurów and Waksmund sections. The assemblage obtained is moderately diverse. The relative abundance of samples usu-

* Supplementary data associated with this article can be found, in the online version, at doi: 10.7306/gq.1425 

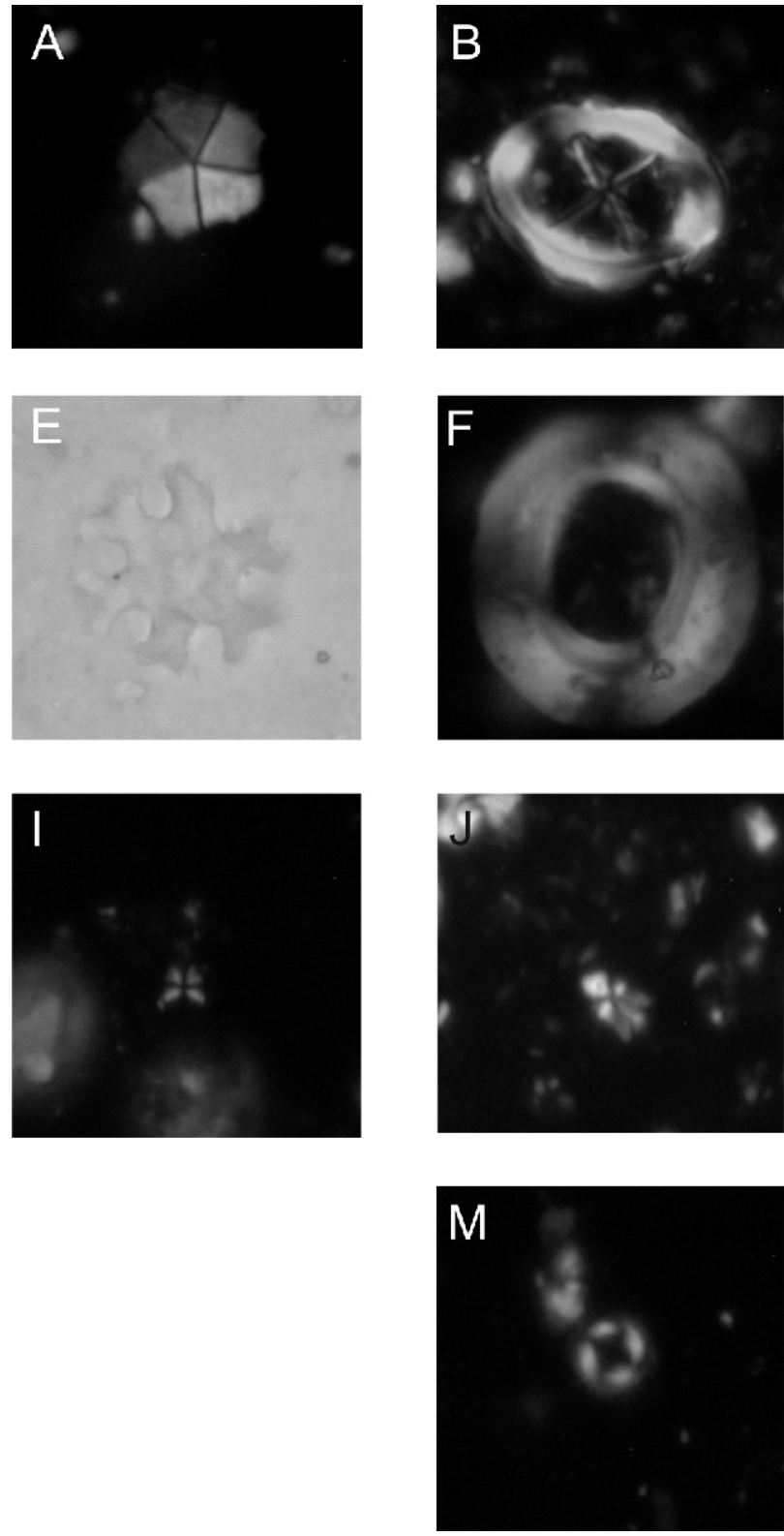
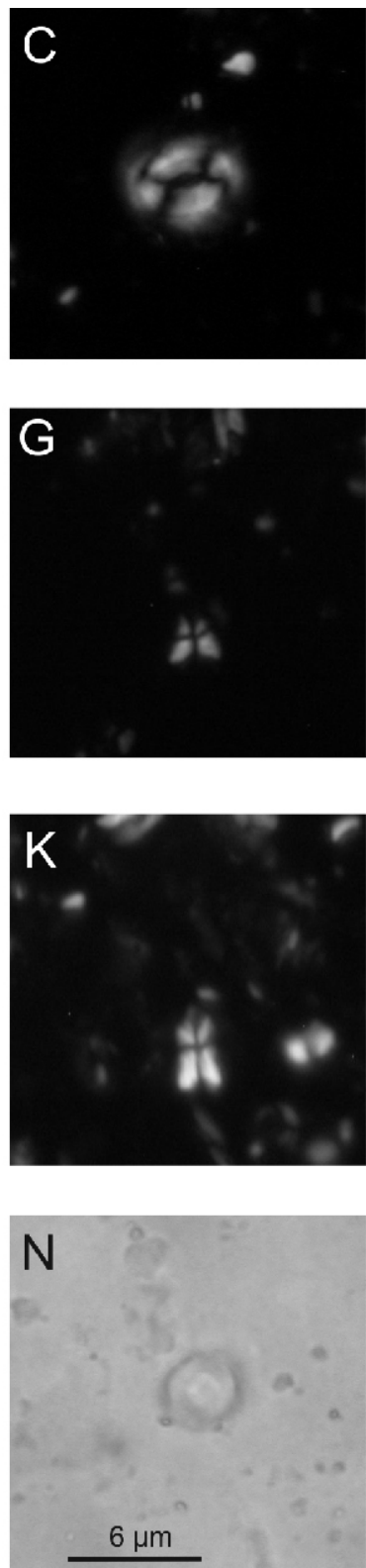
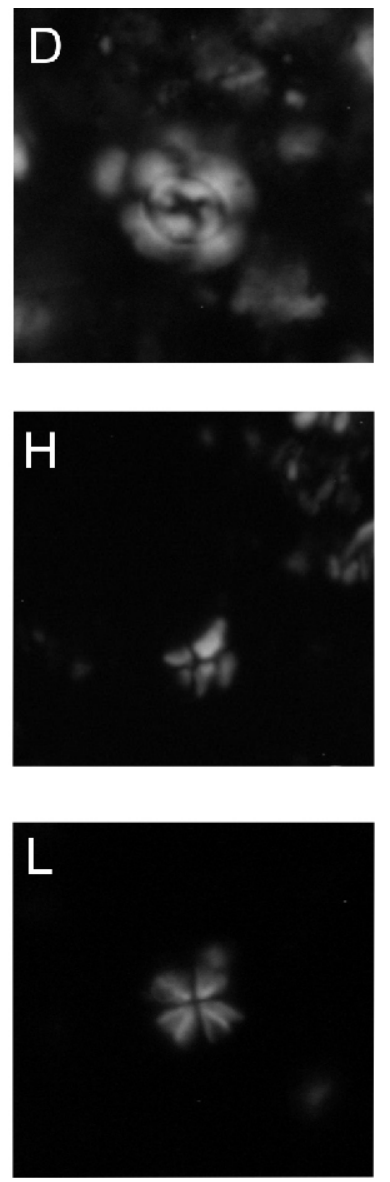

Fig. 14. LM microphotographs of typical nannofossil species

A - Braarudosphaera bigelowii, B - Chiasmolithus modestus, C - Coccolithus pelagicus, D - Cyclicargolithus abisectus, E - Discoaster deflandrei, F - Reticulofenestra umbilica, G-I - Sphenolithus conicus, J, K - Sphenolithus disbelemnos, L - Sphenolithus moriformis, M, N- Umbilicosphaera rotula; A-D, F-M - crossed polars; E, N-parallel polars; scale bar is the same for all photographs

ally ranges from 10 to 15 species per observation field. The difference between the assemblages from these sections is mostly quantitative; qualitatively, the assemblages are similar. They were divided into autochthonous and reworked species, then the percentage of both was calculated in each sample (Appendix 2). As it is highly probable that long-lived species are both autochthonous and reworked, the calculation should be considered as a "minimum reworked ratio"

The autochthonous species include Braarudosphaera bigelowii, Coccolithus pelagicus, C. subpertusus, Coronocyclus nitescens, Cyclicargolithus floridanus, Pontosphaera discopora, P. multipora, Reticulofenestra haque, Sphenolithus calyculus, Sph. conicus, Sph. disbelemnos, Sph. dissimilis, Sph. moriformis, Tetralithoides symeonidesii, Umbilicosphaera rotula and Zygrhabilithus bijugatus.
In most samples from the Huba section the percentage of autochthonous species (Appendix 2) varies from 26 to $34 \%$. The most numerous autochthonous species present in each sample are Coccolithus pelagicus and Sphenolithus moriformis. The percentage variation in the Huba section is shown in Appendix 2.

The percentage of the species Umbilicosphaera rotula is in the range of $1-3 \%$. The species Umbilicosphaera rotula, Pontosphaera discopora and Sphenolithus conicus show in most samples with a similarly fluctuating percentage. Other species such as Braarudosphaera bigelowii, Pontosphaera multipora, Sph. disbelemnos and Sph. dissimilis are irregularly present in the samples. The lowest abundance was noticed in the case of Sph. calyculus and Sph. disbelemnos. 


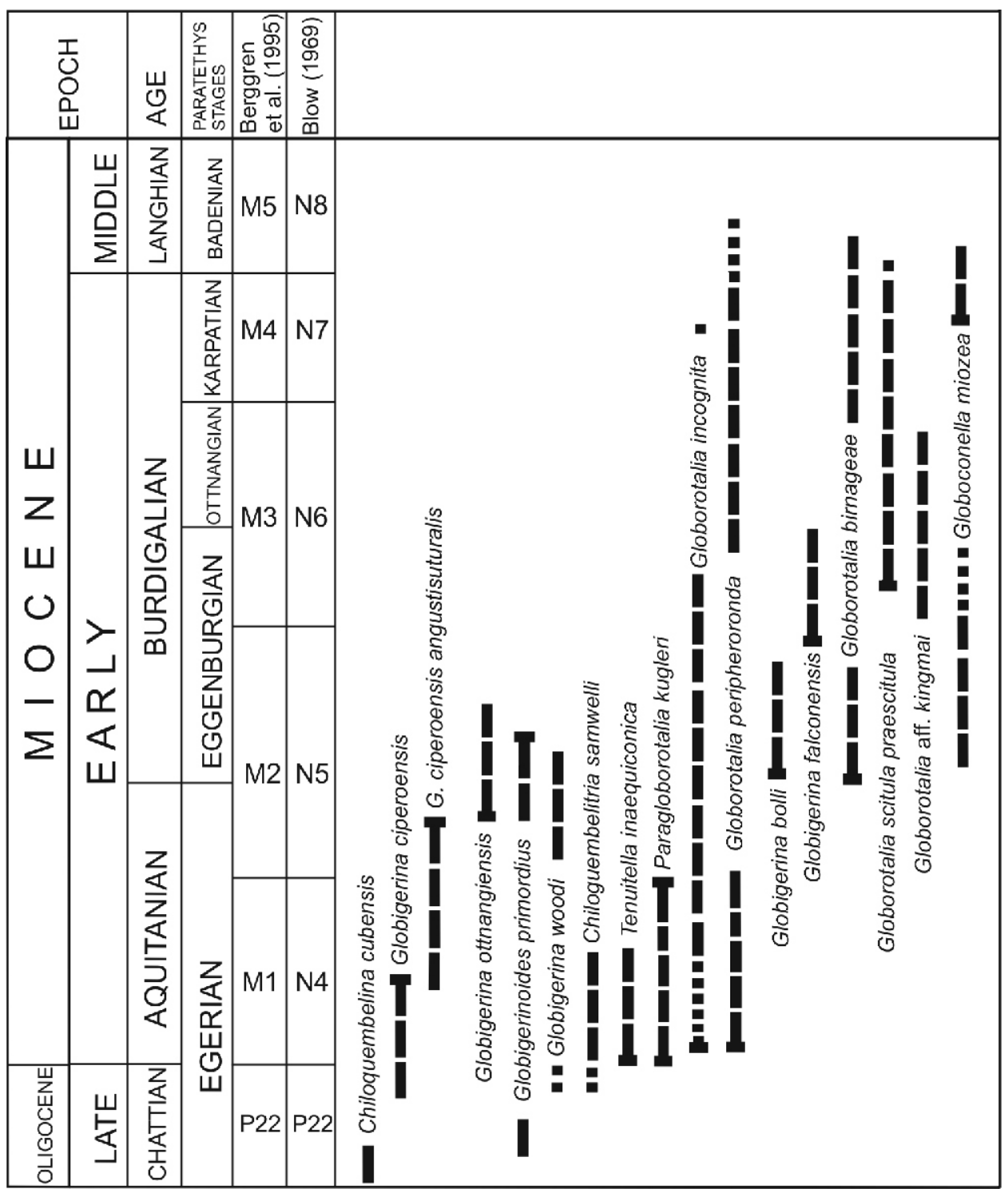

Fig. 15. Stratigraphic assessment of the Kremna Fm. using planktonic foraminifera

Age data are constrained by the biostratigraphic ranges of foraminiferal species, their first and last occurrences (FO, LO), bioevents and zonal markers (see Berggren et al., 1995); overlapping stratigraphical range of foraminiferal species is marked by grey field

The level of reworking is generally high. It varies from $54 \%$ to $68 \%$ for the samples collected from the Huba section (Appendix 2). The reworked assemblage consists of Paleogene and Cretaceous taxa.

The most abundant reworked species in the Huba section include Ericsonia formosa, Toweius crassus, T. rotundus, $T$. selandianus and undivided Cretaceous species (see Appendix 2).

Preservation, species diversity and abundance of foraminiferal microfauna from Stary Stream, and the Szlachtowa and Waksmund sections. Planktonic foraminifera from the Stary Stream section (WP 242-2, WP 242-3) and Waksmund 11 (Nowy Targ 11) sections are reduced in size and abundance. Their association consists of globigerinids, paragloborotaliids, globorotaliids, chiloguembelinids and tenuitellinids (Figs. 15-17). Most common are five-chambered species of Globigerina ciperoensis and Gl. ciperoensis angustisuturalis, which are known mostly from Up- per Oligocene formations. Nevertheless, the LO of Globigerina ciperoensis is marked in the Lower Miocene between the M1 and M2 zones (e.g., Wade et al., 2011), which is also the case for other species (Globigerinoides primordius, Chiloguembelitria samwelli, Globigerina woodi). These species (Fig. 15) are associated, and partly also reworked, with Early Miocene species such as Globigerina ciperoensis ottnangiensis (FO - Zone M2), Paragloborotalia kugleri (Zone M1), Paragloborotalia incognita (Zone M2), Globorotalia mayeri, Globigerina falconensis and Tenuitella inaequiconica. The species Paragloborotalia kugleri is known as an early member of the Neogene globorotaliids and a biostratigraphic marker of Zone M1 (e.g., Keller, 1981; Spezzaferri, 1991; Berggren et al., 1995; Rögl, 1996).

Foraminiferal associations of the Kremna Fm. are specific by the presence and diversity of globorotaliids. Their rounded forms with arched apertures belong to the species Globorotalia (Paragloborotalia) incognita and Glob. peripheroronda. Glob. 

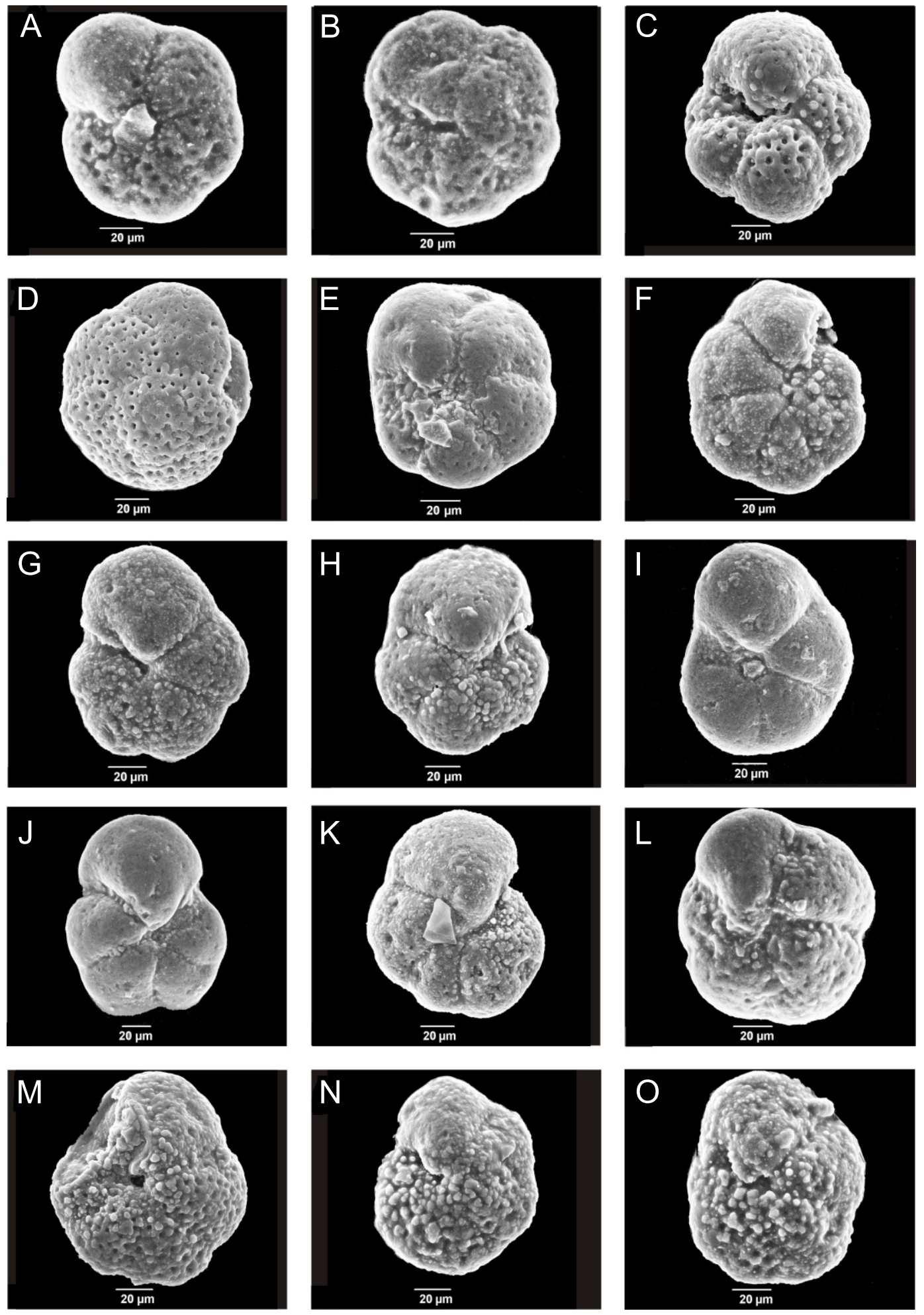

Fig. 16. Paragloborotaliid and globorotaliid species of foraminifers from the Kremna Fm.

A, B - Paragloborotalia kugleri (Bolli, 1957), umbilical sides, Stary Stream, WP 242; C - Paragloborotalia incognita (Walters, 1965), umbilical side, Waksmund 11; D-F - Globorotalia peripheroronda Blow and Banner, 1966: D - spiral side, E - umbilical side, Stary Stream, WP 242, F - umbilical side, Waksmund 11; G-I - Globorotalia scitula praescitula Blow, 1959, umbilical sides: G, H - Waksmund 11, I - Stary Stream, WP 242; J, K Globorotalia cf Glob. archeomenardii Bolli, 1957, umbilical sides: J - Stary Stream, WP 242, K - Waksmund 11; L - Globorotalia birnageae Blow, 1959, umbilical side, Stary Stream, WP 242; M-O - Globoconella miozea (Finlay, 1939), umbilical sides, Waksmund 11 

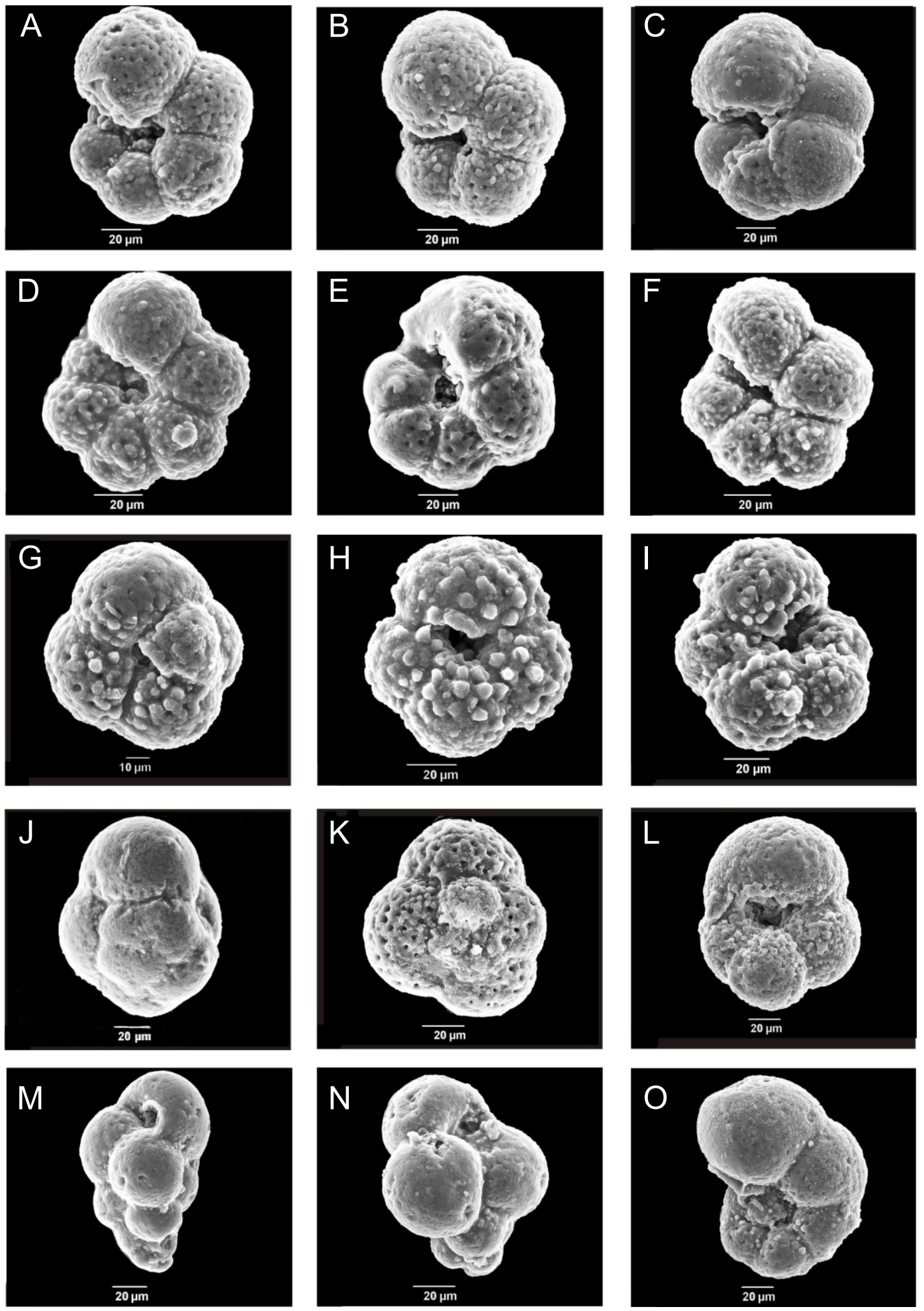

Fig. 17. Globigerinid, chiloguembelinids and tenuitellinid species of foraminifers from the Kremna Fm.

A-C - Globigerina ottnangiensis Rögl, 1969, umbilical sides, Waksmund 11; D, E - Globigerina ciperoensis Bolli, 1954, umbilical sides, Waksmund 11; F - Globigerina ciperoensis angustisuturalis Bolli, 1957, umbilical side, Waksmund 11; G - Globigerina bolli Cita and Premoli Silva, umbilical side, Waksmund 11; H, I Globigerina falconensis Blow, 1959, umbilical sides, Waksmund 11; J, K - Globigerinoides cf. primordius Blow and Banner, 1962, spiral sides: J - Stary Stream, WP 242, K - Waksmund 11; L - Globigerina woodi Jenkins, 1960, umbilical side, Waksmund 11; M, N - Chiloguembelitria samwelli (Jenkins, 1978), side views, Waksmund 11; O - Tenuitella inaequiconica (Subbotina, 1960), umbilical side, Waksmund 11 
(P.) incognita defines the Early Miocene Zone M2/N5 by its appearance between the LO of Paragloborotalia kugleri and FO of Glob. praescitula (Berggren et al., 1995). Glob. peripheroronda evolved from older species of Paraglorotalia kugleri and developed to ancestral forms of the Early Miocene globorotaliids.

\section{INTERPRETATION}

\section{BIOSTRATIGRAPHY}

Calcareous nannofossils. The oldest assemblage among all the samples investigated came from the Skotnicki Stream section. This sample contains an assemblage not older than middle Eocene (NP 16) It is characterized by the presence of Ch. grandis, Cyclicargolithus floridanus, Discoaster barbadiensis, $D$. saipanensis and Ericsonia formosa.

The uppermost part of the Poprad Sandstone Mb. of the Magura Fm. and the basal portion of the Kremna Fm., which are exposed in Biała Woda Stream section, were assigned to NN1. Such a zone assignment is based on a continuous range of Sphenolithus conicus, S. dissimillis and S. delphix following the disappearance of $D$. bisectus (see Oszczypko and Oszczypko-Clowes, 2010, 2014).

A younger age was determined in samples from the Chapel St. Kinga, Kozłecki Stream, Huba, Frydman, Knurów and Waksmund sections. Qualitative studies enabled determination to the Lower Miocene (NN2 Zone). The Discoaster druggii Zone - NN2 is defined between the first appearance of Discoaster druggii, and the last occurrence of Triquetrorhabdulus carinatus (Martini and Worsley, 1970). It is noteworthy that Helicosphaera scissura and $H$. ampliaperta are not present in residual flysch basins; these species are typical of the Pannonian region and the stratotypes of the Eggenburgian (see Holcová, 2002, 2005). The above-mentioned species do not occur in the samples. The coexisting taxa, which were used to determine the biostratigraphic position are as follows: Umbilicosphaera rotula (with a stratigraphic range of NN2-NN16), and Sphenolithus disbelemnos Fornaciari and Rio (1996), ranging NN2-NN3. According to Young (1998), such a nannofossil association is characteristic of the NN2 Zone. The same age was determined from the Stary Stream section (see samples WP242 1-3 in Oszczypko and Oszczypko-Clowes, 2014).

Foraminiferal microfauna from the Kremna Fm. (Stary Stream and Waksmund sections). The presence of Glob. scitula praescitula is considered to be a most important datum, which appeared not before 18.5 Ma (Berggren et al., 1995). This species stratigraphically overlapped the Middle-Upper Burdigalian Zone (N6). The association of globorotaliids is completed by the species Globorotalia birnageae and Glob. cf. kingmai, which are known to have FOs in Zone NN4b (Chaison and Leckie ,1993).

Planktonic foraminifers provide data for a Lower Miocene age of the Kremna Fm. Some of them are Late Oligocene-Early Miocene species of globigerinids (e.g., Globigerina ciperoensis, Globigerinoides primordius, Globigerina woodi), but there are also marker species of the M1 Zone (Paragloborotalia kugleri, Globigerina ciperoensis ottnangiensis). Nevertheless, the presence of descendant species such as Globorotalia peripheroronda and Globorotalia (Paragloborotalia) incognita, points to a younger age (M2/N5 Zone). This is also most evident from the appearance of Globorotalia scitula praescitula at the base of the M3/N 6 Zone (FO - 18.5 Ma), which is associated with other Burdigalian species (Globorotalia birnageae, Glob. cf. kingmai). The important specimens of the assemblage are planktonic foraminifers such as Globoconella miozea and
Globorotalia cf. archeomenardii. The Globorotalia species differ partly in FO datums. The base of Globorotalia (Globoconella) miozea is dated at $16.70 \mathrm{Ma}$ (Berggren et al., 1995), followed by the FO of Globorotalia archeomenardi at 16.50-16.26 Ma (Scott et al., 1990; Wade et al., 2011). However, in the Parathetys, the FO of Globorotalia (Globoconella) miozea is known from the Lower Burdigalian M2 Zone (B. Olszewska, personal communication, 2018). Additionally Globorotalia cf. Glob. archeomenardii, being the conformis species, cannot be the basis for determining a Late Burdigalian age.

Nevertheless, some transitional forms such as Globorotalia pseudomiozea appeared as early as $17.6 \mathrm{Ma}$ in Chron C5Dn (e.g., Berggren, 1977; Keller, 1981). Magnetostratigraphic data reveal the FO of Globorotalia miozea at the beginning of C5Cn.3n (Berggren et al., 1995), while Turner et al. (2007) correlated this bioevent with the slightly older magnetozone $\mathrm{C} 5 \mathrm{Cr}$. The upper limit of the $\mathrm{C} 5 \mathrm{Cr}$ Zone corresponds to $17.6 \mathrm{Ma}$, which is close to the LOs of Sphenolithus disbelemnos and S. conicus in the top of the Burdigalian Stage (17.95 Ma Maiorano and Monechi, 1997; Bown and Dunkley Jones, 2012). These sphenoliths occur also in Ottnangian deposits of nannoplankton zone NN2 and NN3 in the Alpine-Carpathian Foreedep (e.g., Roetzel et al., 2007).

\section{AGE DETERMINATION OF REWORKED NANNOFOSSIL ASSEMBLAGES}

The precise age determination of Paleogene assemblages is not easy, especially as an overlap pattern of several index species is present. The only typical Early Eocene taxa is Discoaster lodoensis (NP12-14). The most abundant taxa are long-ranging species including $D$. barbadiensis (NP10-20), Ericsonia formosa (NP 12-21), Helicosphaera bramlettei (NP14-23), Lanternithus minutus (NP16-22), Reticulofenestra hillae (NP16-22) and R. umbilica (NP16-22).

Their stratigraphic ranges span from the Middle Eocene to the Early Oligocene. These taxa may constitute either Middle Eocene, Late Eocene or even Early Oligocene assemblages. The presence of the Middle Eocene may be dated by Chiasmolithus grandis (NP11-17).

The presence of Isthmolithus recurvus suggests that part of the assemblage may be not older than the NP19/20 Zone (Upper Eocene) and not younger than NP22 (Lower Oligocene), as $R$. umbilica is the index species for the upper limit of Zone NP22.

\section{PALAEOECOLOGY OF KREMNA FORMATION} FROM HUBA SECTION

Quantitative analysis of the coccolith assemblages from the samples collected from the Pod Hubą Stream has allowed a palaeoenvironmental analysis of the deposits studied. For this purpose, account was taken of matching palaeoecological preferences of species in terms of temperature and nutrient content. As noted earlier, long-lived species such as Coccolithus pelagicus and Sphenolithus moriformis are both autochthonous and reworked; the calculation followed by the interpretation should be considered as an approximation of palaeoecological conditions.

Temperature is one of the most important factors influencing the biogeography of calcareous nannoplankton in sedimentary basins (i.e., Wei and Wise, 1990 and references therein; Wei et al., 1992; Agnini et al., 2006; Gibbs et al., 2006, Villa et al., 2008 and references therein). Based on the analysis of autochthonous species, the assemblages are dominated by cold water taxa. Among these, Coccolithus pelagicus and 
Cyclicargolithus floridanus are the most characteristic. C. pelagicus is today a subpolar species. Its preferred water temperature ranges from -1.5 to $+15^{\circ} \mathrm{C}$, and its largest concentration is at temperatures of $2-12^{\circ} \mathrm{C}$ (Okada and Mclntyre, 1979. Winter et al., 1994, Ćorić and Rögl, 2004). Therefore, Coccolithus pelagicus is widely used as a palaeotemperature proxy for cold waters in palaeoceanographic studies, as a qualitative/semiquantitative parameter (Mclntyre and Bé, 1967 1970). In contrast to such an interpretation are the results of Cachao and Moita (2000) showing that Coccolithus pelagicus occurs in the Iberian upwelling system. Hence, the presence of C. pelagicus off Iberia and other areas such as northwestern and southwestern Africa, suggests that this species has an affinity to upwelling areas. C. pelagicus optimum conditions and maximum temperatures can be extended to 16 and $18^{\circ} \mathrm{C}$. At high latitudes Cyclicargolithus floridanus is practically not present. It is, however, found in temperate latitudes, less frequent high or lower ones (Wei and Wise, 1990). Species preferring moderate water include also Coronocyclus nitescens and Umbilicosphaera rotula.

The only warm-water species is Sphenolithus moriformis. It is more common in low latitudes than in high ones. It was also more common around the continents or seamounts than in the open ocean (Perch-Nielsen, 1985).

\section{DISCUSSION}

Between the Biała Woda Valley in the east and the Biały Dunajec River in the west (Fig. 2), there is a morphological and tectonic depression between the southern slope of the Gorce and Beskid Sądecki ranges and the PKB. This depression is occupied by the deposits of the Kremna Fm. (Aquitanian-Burdigalian), formerly known as the Szczawnica Fm. (Upper Paleocene/Lower Eocene, see Burtan et al.,1981; Birkenmajer and Oszczypko, 1989 and references therein), This formation is composed mainly of thin- to medium-bedded turbidites with intercalations of dark marly mudstones. There are also subordinate thick-bedded sandstones and exotic conglomerates, as well as thick beds of Łącko-type marls. East of the Biała Woda fault, the Kremna Fm. overlies the PoSM of the Magura Fm. (Upper Oligocene). Similar relationships have been identified by some of us (Oszczypko et al., 2005a; Oszczypko and Oszczypko-Clowes, 2010, 2014) near Kremna (East Slovakia) and along the Polish-Slovak border (Dubne-Ruska Vola) near Leluchów. The Kremna Fm. type of deposits has been recognized also between Eastern Slovakia (Laborec Beds, Humenné area; Matašovsky and Andreyeva-Grigorovich, 2002) and the Horna Orava region in Western Slovakia (Oszczypko-Clowes et al., 2013), at a distance of $\sim 200 \mathrm{~km}$. Probably, deposits similar to the Kremna Fm. continue, along the PKB to the east, up to the Ukrainian Carpathians (e.g., Drahovo Fm. of the Marmarosh Flysch, see Oszczypko et al., 2005b; Hnylko and Hnylko, 2016). Oligocene/Miocene deposits, similar to the Kremna Fm., have been recognized as the Zawada Fm. south of Nowy Sącz in the Rača Sub-unit of the Magura Nappe (Oszczypko et al., 1999; Oszczypko and Oszczypko-Clowes, 2002). The presence of the Kremna Fm. in the Bystrica Sub-unit is also not excluded.

The results of our research suggests that around the Oligocene/Early Miocene boundary in the Polish part of the OWC, there were two residual flysch basins: a southern one located in front of the uplifted PKB, and the CWC. The narrow residual Magura basin was located at the front of the PKB, between Humenné in the east and the Horna Oravá region in the west. The northern residual basin was located on the European Platform, in front of the overriding accretionary wedge of the
Carpathian flysch nappes. In the Middle Miocene this basin was transformed into the Carpathian Foredeep (e.g., Kováč et al., 2016, 2017). On this basis it can be inferred that Oligocene/Miocene sediments were deposited in a narrow residual Magura Basin.

On the basis of palaeotransport measurements it can be concluded that the Kremna-Zawada Basin was supplied from the SE, probably from the South Magura source area, which was active during the Paleogene (Oszczypko et al., 2016; Kovač et al., 2016). To a small extent, the Kremna Basin may have been supplied from the partially emergent PKB. This is suggested by the presence of small olistoliths of Upper Jurassic limestones in the Kremna Fm. (the Durbaszka Massif along the Polish/Slovak boundary, Oszczypko and Oszczypko-Clowes, 2014). These deposits formerly have been assigned to the Eocene/Oligocene as the Złatny Beds (e.g., Golonka and Rączkowski, 1984). Recently, Golonka et al. (2015) distinguished two stages of olistostrome formation; during the Late Cretaceous/Paleocene (e.g., Jarmuta Basin) and during the Paleogene (e.g., Zlatna Basin).

The palaeogeographical position of the Kremna-Zawada Basin is shown on Figure 18. The Kremna Fm. could be regarded as synorogenic deposits of the residual Magura Basin, developed in the course of the orogenic shortening and uplifting of the Western Outer Carpathians. The Kremna-Zawada Basin may be regarded as a kind of "piggyback basin" which developed simultaneously with the onset of formation of the Carpathian Foredeep at the front of the WOC orogen. This is documented by the Aquitanian transgressive deposits over the platform basement and beneath the Carpathian overthrust, recognized west of Kraków in the Andrychów 6 borehole (Oszczypko and Oszczypko-Clowes, 2003).

The tectonic contact of the Kremna/Zawada residual basin with the PKB was active after the Burdigalian and until the Sarmatian. During that interval, this contact zone was periodically dominated both by stretching/subsiding/deposition periods as well as by periods of compression (thrusting and strike-slip faulting). In a broader regional perspective, the Oligocene and Early Miocene evolution of the Western Outer Carpathian basins, including the Kremna/Zawada Basin, are discussed extensively in recent publications by Kovač et al. (2016, 2017).

The Early Miocene foraminiferal microfauna of the Kremna Fm. provides an important insight into the palaeogeography of the Magura Basin. Similar associations of Early Miocene foraminifers have been described from the Zawada Fm. (Oszczypko et al., 1999), Zebrzydowice and Vorotyshche fms. of the Carpathian Foredeep and Stebnik/Stebnyk Unit (Subbotina, 1960; Odrzywolska-Bieńkowa and Olszewska, 1996; Garecka and Olszewska, 1997, 1998), the Lower Miocene formations of the Waschberg Unit and Nord Alpine Foreland Basin (Rögl and Nagymarosy, 2004; Roetzel et al., 2006; Grunert et al., 2010a, b, c), and the Hida Formation of the Transylvanian Basin (Filipescu and Beldean, 2008; Beldean and Filipescu, 2012). The most important components of this microfauna are globorotaliids, which are known mainly from the Indo-Pacific area. The presence of abundant globorotaliids in the Lower Miocene formations of the Magura Basin implies its communication with the Indo-Pacific Ocean and the inflow of open marine waters. The appearance of the Globorotalia praescitula coincided with the onset of the major cool temperate event Milb (Scott et al., 1995), which is also constrained in the Central Paratethys to about 17.8 Ma (Grunert et al., 2010a, b, c). Descendant species like Globoconella miozea developed a crust in response, to inhabit cool-water masses of mesopelagic and bathypelagic environments (Scott, 1972). Therefore, globorotaliids of the praescitula-miozea lineage provide the 


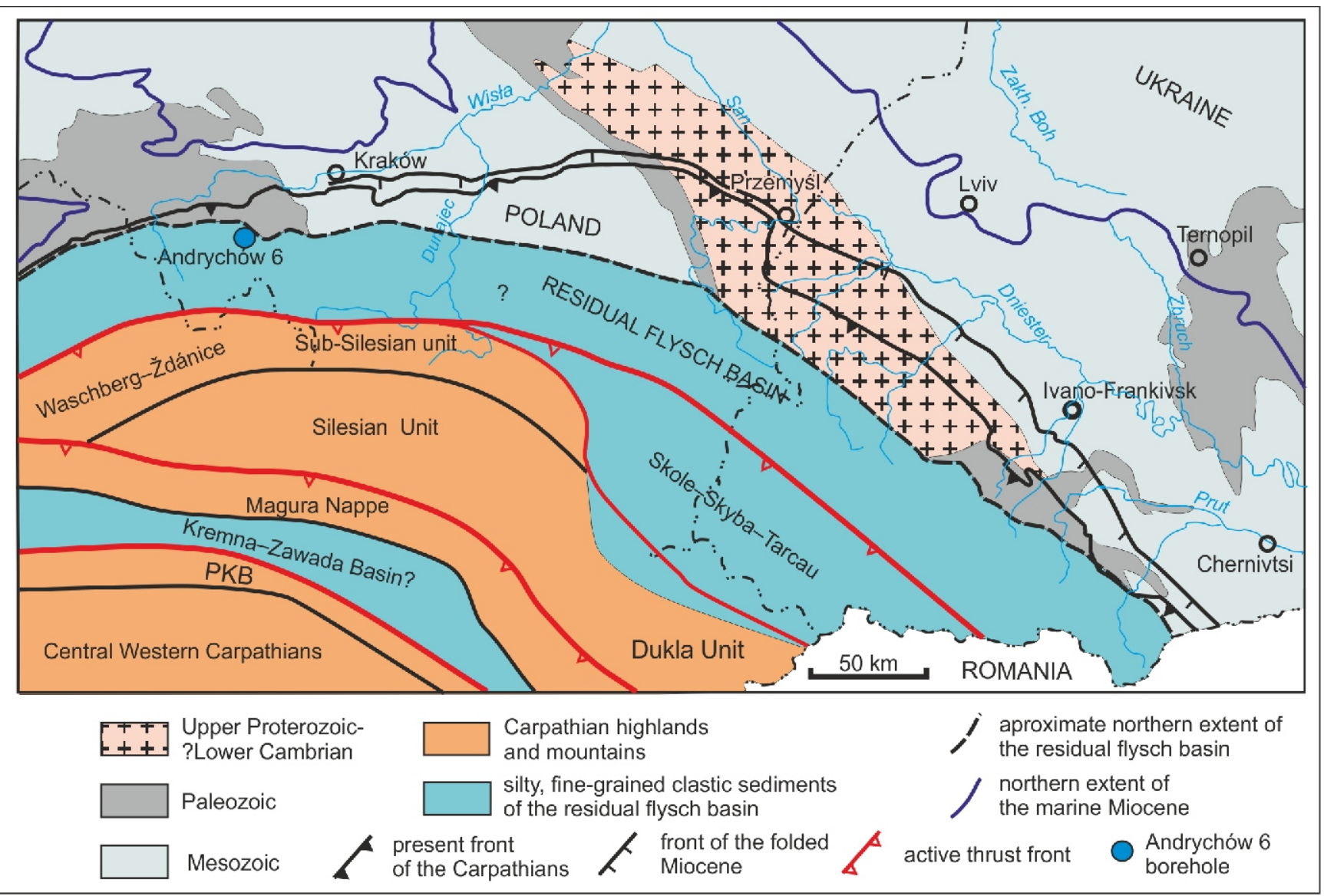

Fig. 18. Early Burdigalian palinspastic palaeogeographic map of the northern sector of the Western Carpathian basin system (based on Oszczypko et al., 2016, supplemented)

principal bioevents for the late Early Miocene zonation of subarctic and transitional areas (Berggren et al., 1995). Early Miocene climatic cooling facilitated a migration of Globorotalia praescitula and another keeled and encrusted globorotaliids from high to middle and low latitudes. They also occupied deep-water environments of the Early Miocene Magura Basin.

The Early Miocene flysch basin of the Magura Nappe differs considerably from surrounding basins of the Carpatho-Pannonian realm by deep- and cool-water conditions, an absence of the mixed layer and warm to temperate-water planktonic species (e.g., Globigerinoides species, helicosphaerids). Such morphotypes of globorotaliid and globoconellid species belong to thermocline habitats, which reproduced in waters colder and deeper than those of the surface mixed layer species (Keller, 1985; Norris et al., 1994). This points to depth stratification and circulation of water masses in a deep-water basin. Moreover, globorotaliid species such as Glob. praescitula were opportunistic forms (Scott et al., 1995), indicating a high level of trophic resources, which may have been elevated by upwelling activity in the Magura residual basin. In mid-Burdigalian time, upwelling conditions were also recorded along the Paratethyan coasts (e.g., Roetzel et al., 2006; Grunert et al., 2010a, b, c).

\section{CONCLUSIONS}

1. In the tectonic depression between the PKB and the Gorce-Beskid Sądecki ranges, the Kremna Formation flysch deposits, up to $1000 \mathrm{~m}$ thick, have been recognized.

2. The age of these deposits, formerly known as Late Paleocene/Early Eocene Szczawnica Fm., is determined to be Aquitanian/Burdigalian, based on new research on calcareous nannoplankton and foraminifera.

3. Palaeotransport measurements indicate sediment supply from the SE.

4. A significant amount of reworked foraminifera and calcareous nannoplankton suggests the feeding of flysch material from Eocene erosional massifs.

5 . The length of the residual Kremna/Zawada Basin, open to the east, was at least $200 \mathrm{~km}$ and the width was $\sim 50 \mathrm{~km}$.

6. The late Miocene/Pliocene Nowy Targ-Orava Basin is a successor structure to the Kremna Basin.

Acknowledgements. The author wishes to thank K. Holcova, M. Krobicki and anonymous reviewers for their constructive criticism and detailed review of the manuscript. This research has been supported by the Jagiellonian University (DS founds) and partially financed from APVV-14-0118 a, VEGA 2/0034/16. 


\section{REFERENCES}

Agnini, C., Muttoni, G., Kent, D.V., Rio, D., 2006. Eocene biostratigraphy and magnetic stratigraphy from Possagno, Italy: the calcareous nannofossil response to climate variability. Earth and Planetary Science Letters, 241: 815-830.

Alexandrowicz, S.W., Bogacz, K., Wacławik, S., 1966. Piaskowce litamniowe we flszu magurskin okolic Krościenka nad Dunajcem (in Polish). Zeszyty Naukowe AGH, Geologia, 7: 39-61.

Alexandrowicz, S.W., Cieszkowski, M., Golonka, J., Kutyba, J., Oszczypko, N., Paul, Z., 1984. The stratigraphy of the Krynica Zone of the Magura Nappe in the Polish Flysch Carpathians (in Polish with English summary). Biuletyn Instytutu Geoleologicznego, 340: 23-43.

Aubry, M.P., 1984. Handbook of Cenozoic calcareous nannoplankton, 1: Ortholithae (Discoasters). Micropaleontology Press, American Museum of Natural History, New York.

Aubry, M.P., 1988. Handbook of Cenozoic calcareous nannoplankton, 2: Ortholithae (Holochoccoliths, Ceratoliths and others). Micropaleontology Press, American Museum of Natural History, New York.

Aubry, M.P., 1989. Handbook of Cenozoic calcareous nannoplankton, 3: Ortholithae (Pentaliths, and others) Heliolithae (Fasciculiths, Sphenoliths and others) Micropaleontology Press, American Museum of Natural History, New York

Aubry, M.P., 1990. Handbook of Cenozoic calcareous nannoplankton, 4: Heliolithae (Helicoliths, Cribriliths, Lopadoliths and others). Micropaleontology Press, American Museum of Natural History, New York, 381 pp.

Aubry, M.P., 1999. Handbook of Cenozoic calcareous nannoplankton, 5: Heliolithae (Zygolithus and Rhabdolithus) Micropaleontology Press, American Museum of Natural History, New York.

Beldean, C., Filipescu, S., Balc, R., 2012. Paleoenvironmental and biostratigraphic data for the Early Miocene of the North-Western Transylvanian Basin based on planktonic foraminifera Carpathian Journal of Earth Environmental Sciences, 7 171-184.

Berggren, W.A., 1977. Late Neogene planktonic foraminiferal biostratigraphy of the Rio Grande Rise (South Atlantic). Marine Micropaleontology, 2: 265-313.

Berggren, W.A., Kent, D.V., Swisher, C.C., Aubry, M.-P., 1995. A revised Cenozoic geochronology and chronostratigraphy. SEPM Special Publication, 54: 129-212.

Bindiu, R., Filipescu, S., Balc, R., Cocic, L., Gligor, D., 2015. The middle/late Eocene transition in the Eastern Carpathians (Romania) based on foraminifera and calcareous nannofossil assemblages. Geological Quarterly, 60 (1): 38-55.

Birkenmajer, K., 1979. Przewodnik geologiczny po pienińskim pasie skałkowym Polski (in Polish). Wyd. Geol., Warszawa.

Birkenmajer, K., 1986. Stages of structural evolution of the Pieniny Klippen Belt, Carpathians. Studia Geologica Polonica, 88: 7-32.

Birkenmajer, K., Dudziak, J., 1981. Age of the Magura flysch, Palaeogene, along the northern boundary of the Pieniny Klippen Belt, Carpathians, based on nanoplankton (in Polish with English summary). Studia Geologica Polonica, 70: 7-36.

Birkenmajer, K., Oszczypko, N., 1989. Cretaceous and Palaeogene litostratigraphic units of the Magura Nappe, Krynica Subunit, Carpathians. Annales Societatis Geologorum Poloniae, 59: 145-181.

Blow, W.H., 1969. Late Middle Eocene to Recent planktonic foraminiferal biostratigraphy. In: Proceedings of the first International Conference on Planktonic Microfossils (Geneva, 1967) (eds. P. Bronnimann and H.H. Renz), 1: 199-421. E.J. Brill, Leiden.

Bolli, H.M., 1957. Planktonic foraminifera from the Oligocene-Miocene Cipero and Lengua Formations of Trinidad, B.W.I. Bulletin of the U.S. National Museum, 215: 97-103.

Bown, P.R., Dunkley Jones, T., 2012. Calcareous nannofossils from the Paleogene equatorial Pacific (IODP Expedition 320
Sites U1331-1334). Journal of Nannoplankton Research, 3: 3-51.

Bown, P., 1998. Calcareous Nannofossils Biostratigraphy. British Micropalaeontological Society Publications Series, Chapman and Hall/Kluwer Academic Publishers, London.

Burtan, J., Golonka, J., Oszczypko, N., Paul, Z., Ślączka, A., 1981. Mapa geologiczna Polski arkusz Nowy Sącz, B - bez utworów czwartorzędowych (in Polish). Wyd. Geol., Warszawa.

Cachao, M., Moita, M.T., 2000. Coccolithus pelagicus, a productivity proxy related to moderate fronts off Western Iberia. Marine Micropaleontology, 39: 131-155.

Chaisson, W.P., Leckie, M.R., 1993. High-resolution Neogene planktonic foraminifer biostratigraphy of site 806 , Ontong Java Plateau (western equatorial Pacific). Proceedings of the Ocean Drilling Program, Scientific Results, 130: 137-178.

Chrustek, M., Golonka, J., Janeczko, A., Stachyra, F., 2005. Geological characterisation of the Krynica Subunit in the vicinity of Krościenko on the Dunajec River (Magura Nappe, Outer Flysch Carpathians (in Polish with English summary). Geologia, 31: 127-144.

Cieszkowski, M., 1992. Marine Miocene deposits near Nowy Targ, Magura Nappe, Flysch Carpathians (South Poland). Geologica Carpathica, 46: 339-346

Cieszkowski, M., 1995. Utwory morskiego miocenu w rejonie Nowego Targu i ich znaczenie dla określenia czasu powstania śródgórskiego zapadliska Kotliny Orawsko-Nowotarskiej (in Polish). Geologia, 21: 153-168.

Cieszkowski, M., Olszewska, B., 1986. Malcov Beds in Magura Nappe near Nowy Targ, Outer Carpathians, Poland. Annales Societatis Geologorum Poloniae, 56: 53-71.

Cieszkowski, M., Olszewska, B., Smagowicz, M., 1993. Utwory morskiego miocenu w okolicy Nowego Targu (in Polish). Sprawozdania z posiedzeń Komisji Naukowych PAN, Oddz. Kraków, styczeń-grudzień 1991, 39: 245-249.

Ćorić, S., Rögl, F., 2004. Roggendorf-1 Borehole, a key-section for Lower Badenian transgressions and the stratigraphic position of the Grund Formation (Molasse Basin, Lower Austria). Geologica Carpathica, 55: 165-178.

Filipescu, S., Beldean, C., 2008. Foraminifera in the deep-sea environments of the Lower Hida Formation (Transylvanian Basin, Romania). Acta Palaeontologica Romaniae, 6: 105-114.

Fornaciari, E., Rio, D., 1996. Latest Oligocene to early middle Miocene quantitative calcareous nannofosil biostratigraphy in the Mediterranean region. Micropaleontology, 42: 1-36.

Fornaciari, E., di Stefano, A., Rio, D., Negri, A., 1996. Middle Miocene quantitative calcareous nannofosil biostratigraphy in the Mediterranean region. Micropaleontology, 42: 38-64.

Garecka, M., Olszewska, B., 1997. On stratigraphy of the Stebnik Unit in Poland. Przegląd Geologiczny, 45: 793-798.

Garecka, M., Olszewska, B., 1998. Biostratigraphy of the early Miocene of the Southern Poland based on planctonic foraminifera and calcareous nannoplankton (in Polish with English summary). Przegląd Geologiczny, 46: 712-720.

Gibbs, S.J., Bralower, T.J., Bown, P.R., Zachos, J.C., Bybell, L., 2006. Shelf and open-oceancalcareous phytoplankton assemblages across the Paleocene-Eocene thermal maximum: implications for global productivity gradients. Geology, 34: 233 -236.

Golonka, J., Rączkowski, W., 1981. Szczegółowa mapa geologiczna Polski, arkusz Piwniczna (in Polish). Wyd. Geol., Warszawa.

Golonka, J., Rączkowski, W., 1984. Objaśnienia do Szczegółowej mapy geologicznej Polski, arkusz Piwniczna (in Polish). Wyd. Geol., Warszawa.

Golonka, J., Waśkowska, A., 2014. Paleogene of the Magura Nappe adjacent to the Pieniny Klippen Belt between Szczawnica and Krościenko (Outer Carpathians, Poland). Geology, Geophysics and Environment, 40: 359-376.

Golonka, J., Krobicki, M., Oszczypko, N., Salata, D., 2006. Conference Excursion 2, Stop 7. Krościenko-Zawiasy Klippen-Con- 
tact Zone between the Pieniny Klippen Belt and the Magura Nappe. Proceedings of the 4th Meeting of Central European Tectonic Studies Group/ 11th Meeting of the Czech Tectonic Studies Group/7thCarpathian Tectonic Workshop Zakopane, Poland, April 19-22, 2006, Geolines, 20: 182-183.

Golonka, J., Krobicki, M., Waśkowska, A., Cieszkowski, M., Ślączka, A., 2015. Olistostromes of the Pieniny Klippen Belt, Northern Carpathians. Geological Magazine, 152: 269-286.

Gonera, M., 2013. Globorotaliid intervals of the sub-evaporite Badenian (Middle Miocene) in the Upper Silesia Basin (Central Paratethys, Poland). Geological Quarterly, 57 (4): 757-768.

Grunert, P., Harzhauser, M., Piller, W.E., 2010a. Mid-Burdigalian cooling of Central Europe - Impact of local tectonics and global climate. Geophysical Research Abstract, 12, EGU20 10-2618.

Grunert, P., Soliman, A., Harzhauser, M., Müllegger, S., Piller, W.E., Roetzel, R., Rögl, F., 2010b. Upwelling conditions in the Early Miocene Central Paratethys Sea. Geologica Carpathica, 61: 129-145.

Grunert, P., Harzhauser, M., Rögl, F., Sachsenhofer, R., Gratzer, R., Soliman, A., Piller W.E., 2010c. Oceanographic conditions as a trigger for the formation of an Early Miocene (Aquitanian) Konservat-Lagerstätte in the Central Paratethys Sea. Palaeogeography, Palaeoclimatology, Palaeoecology, 292: 425-442.

Halicki, B., 1959. Contributions of the geology of the Podhale Region (in Polish with English summary). Biuletyn Instytutu Geologicznego, 145: 241-249.

Hnylko, S., Hnylko, O., 2016. Foraminiferal stratigraphy and palaeobathymetry of Paleocene-lowermost Oligocene deposits (Vezhany and Monastyrets nappes, Ukrainian Carpathians). Geological Quarterly, 60 (1): 77-105.

Holcová, K., 2002. Calcareous nannoplankton from the Eggenburgian stratotypes (Lower Miocene, Central Paratethys). Geolgica Carpathica, 53: 381-390.

Holcová, K., 2005. Quantitative calcareous nannoplankton biostrati-graphy of the Oligocene/Miocene boundary interval in the northern part of the Buda Basin (Central Paratethys). Geological Quarterly, 49 (3): 260-274.

Horwitz, L., 1935. Nouvelle coupe schematique de la Zone Pienine des Klippes (Karpates Polonaise) (in Polish with French summary). Sprawozdania z Posiedzeń Państwowego Instytutu Geologicznego, 8: 79-105.

Horwitz, L., 1963. Geological structure of Pieniny Mts, Carpathians (in Polish with English summary). Prace Geologiczne, 38.

Kaczmarek, A., Oszczypko-Clowes, M., Cieszkowski, M., 2016. Early Miocene age of the Stare Bystre Formation. Geological Quarterly, 60 (2): 341-354.

Keller, G., 1981. The genus Globorotalia in the Early Miocene of the equatorial and northwest Pacific. Journal of Foraminiferal Research, 11: 118-132.

Keller, G., 1985. Depth stratification of planktonic foraminifers in the Miocene ocean. GSA Memoir, 163: 177-195.

Kennet, J.P., Srinivasan, M.S., 1983. Neogene Planktonic Foraminifera - A Phylogenetic Atlas. Hutchinson Ross Publishing Company, Stroudsburg, Pennsylvania.

Kováč, M., Plašienka, D., Soták, J., Vojtko, R., Oszczypko, N., György, L., Ćosović, V., Fügenschuh, B., Králiková, S., 2016. Paleogene palaeogeography and basin evolution of the Western Carpathians, Northern Pannonian domain and adjoining areas. Global and Planetary Change, 140: 9-27.

Kováč, M., Márton, E., Oszczypko, N., Vojtko, R., Hók, A., Králiková, S., Plašienka, D., Klučiar, T., Hudáčková, N., Oszczypko-Clowes, M., 2017. Neogene palaeogeography and basin evolution of the Western Carpathians, Northern Pannonian domain and adjoining areas. Global and Planetary Change, 155: 133-154.

Książkiewicz, M., 1972. Budowa geologiczna Polski, I, część 3, Karpaty (in Polish). Wyd. Geol., Warszawa.

Książkiewicz, M., 1977. The Tectonics of the Carpathians. In: Geology of Poland (ed. W. Pożaryski), Tectonics, IV: 476-669. Wyd. Geol., Warszawa

Książkiewicz, M., Leško, B., 1959. On relation between the Krosno- and Magura-Flysch. Bulletin of the Polish Academy of Sciences, Earth Sciences, 7: 773-780.
Kulka, A., Rączkowski, W., Żytko, K., Gucik, S., Paul, Z., 1987. Szczegółowa mapa geologiczna Polski, arkusz SzczawnicaKrościenko (in Polish). Wyd. Geol., Warszawa.

Kulka, A., Rączkowski, W., Żytko, K., Gucik, S., Paul, Z., 1991. Objaśnienia do Szczegółowej mapy geologicznej Polski, arkusz Szczawnica-Krościenko (in Polish). Wyd. Geol., Warszawa.

Leško, B., Samuel, O., 1968. Geologia Vychodoslovenskoho Flysu (in Slovak). Vydav. Slov. Akad. Vied, Bratislava.

Maiorano, P., Monechi S., 1997. New Early Miocene species of Sphenolithus DEFLANDRE, 1952 from the Noth Atlantic Ocean. Journal of Nannoplankton Research, 19: 103-107.

Martini, E., Worsley, T., 1970. Standard Neogene calcareous nannoplankton zonation. Nature, 225: 289-290.

Matašovsky, M., Andreyeva-Grigorovich, A.S., 2002. The Lower Miocene deposits of the Krynica Subunit of the Magura Nappe near Humenne (eastern Slovakia). In: Paleogeographical, Paleoecological and Paleoclimatic Development of Central Europe (eds. J. Michalik, N. Hudačková, B. Chalupová and D. Starek): 63-64. Conference in Bratislava, Abstract Book.

Matějka, A., 1959. Sector de Šariš de la zone des Klippes internes entre le Poprad et le Sekčovsky potok. Zprávy o geologických výzkumech v Roce 1957, Praha.

McIntyre, A., Bé, A.H., 1967. Modern Coccolithophoridae of the Atlantic Ocean. Deep Sea Research, 14: 561-597.

McIntyre, A., Bé, A.H., 1970. Modern Pacific coccolithophorida: a paleontological thermometer. Transactions of the New York Academy of Sciences, 11: 720-731.

Norris, R.D., Corfield, R.M., Cartlidge, J.E., 1994. Evolutionary ecology of Globorotalia (Globoconella) (planktic foraminifera). Marine Micropaleontology, 23: 121-145.

Odrzywolska-Bieńkowa, E., Olszewska, B., 1996. Fauna - Invertebrates; Rząd Foraminiferida Eichwald 1830 (in Polish). In: Geological structure of Poland (eds. L. Malinowska and M. Piwocki), III: Atlas of index and characteristic fossils. Część 3a, 2: 530-613.

Okada, H., McIntyre, A., 1979. Seasonal distribution of the modern Coccolithophores in the western North Atlantic Ocean. Marine Biology, 54: 319-328.

Oszczypko, N., 1973. The geology of the Nowy Sącz Basin (the Middle Carpathians) (in Polish with English summary). Biuletyn Instytutu Geologicznego, 271: 101-197.

Oszczypko, N., 1997. The early-middle Miocene Carpathian peripheral foreland basin (Western Carpathias, Poland). Przegląd Geologiczny, 45: 1054-1063.

Oszczypko, N., Oszczypko-Clowes, M., 2002. Newly discovered Early Miocene deposits in the Nowy Sącz area (Magura Nappe, Polish Outer Carpathians). Geological Quarterly, 46 (2): 117-133.

Oszczypko, N., Oszczypko-Clowes, M., 2010. The Paleogene and early Neogene stratigraphy of the Beskid Sądecki Range and Lubovnianska Vrchovina (Magura Nappe, Western Outer Carpathians). Acta Geologica Polonica, 60: 317-348.

Oszczypko, N., Oszczypko-Clowes, M., 2014. Geological structure and evolution of the Pieniny Klippen Belt to the east of the Dunajec River - a new approach (Western Outer Carpathians, Poland). Geological Quarterly, 58 (4): 737-758.

Oszczypko, N., Dudziak, J., Malata, E., 1990. Stratigraphy of the Cretaceous through Palaeogene deposits of the Magura Nappe in the Beskid Sądecki Range, Polish Outer Carpathians (in Polish with English summary). Studia Geologica Polonica, 97: 109-181.

Oszczypko, N., Andreyeva-Grigorovich, A., Malata, E., Oszczypko-Clowes, M., 1999. The Lower Miocene deposits of the Rača Sub-Unit near Nowy Sącz (Magura Nappe, Polish Outer Carpathians). Geologica Carpathica, 50: 419-433.

Oszczypko, N., Oszczypko-Clowes, M., Golonka, J., Marko, F., 2005a. Oligocene-Lower Miocene sequences of the Pieniny Klippen Belt and adjacent Magura Nappe between Jarabina and the Poprad River (East Slovakia and South Poland) - their tectonic position and paleogeographic implications. Geological Quarterly, 49 (4): 379-402.

Oszczypko, N., Oszczypko-Clowes, M., Golonka, J., Krobicki, M., 2005b. Position of the Marmarosh Flysch (Eastern 
Carpathians) and its relation to the Magura Nappe (Western Carpathians). Acta Geologica Hungarica, 48: 259-282.

Oszczypko, N., Salata, D., Konečný, P., 2016. Age and provenance of mica-schist pebbles from the Eocene conglomerates of the Tylicz and Krynica Zone (Magura Nappe, Outer Flysch Carpathians). Geologica Carpathica, 67: 257-271.

Oszczypko-Clowes, M., 2001. The nannofossil biostratigraphy of the youngest deposits of the Magura Nappe (East of the Skawa river, Polish Flysch Carpathians) and their palaeoenviromental conditions. Annales Societatis Geologorum Poloniae, 71 139-188.

Oszczypko-Clowes, M., Oszczypko, N., 2003. The Aquitanian marine deposits in the basement of the Polish Western Carpathians and its paleogeographical and paleotectonic implications. Acta Geologica Polonica, 53: 101-122.

Oszczypko-Clowes, M., Sotak, J., Oszczypko, N., Šurka, J., 2013. Biostratigraphy revision of the Magura Unit in the Horna Orava region (Slovakia): constraints for Oligomiocene formations. GESEWEC 2013, Smolenice, Slovakia, 16-19, October, 2013. Geological evolution of the Western Carpathians: new ideas in the field of Inter-regional correlation: 66-67. Geological Institute Slovak Academy of Sciences, Bratislava.

Paul, Z., Poprawa, D., 1992. Geology of the Magura Napppe in the Peri-Pieniny Zone in light of the Nowy Targ PIG 1 borehole (in Polish with English summary). Przegląd Geologiczny, 40: 404-409.

Perch-Nielsen, K., 1985. Cenozoic calcareous nannofossils. In Plankton Stratigraphy (eds. H. Bolli, J.S. Saunders and K. Perch-Nielsen): 427-554. Cambridge University Press.

Roetzel, R., Ćorić, S., Galović, I., Rögl, F., 2006. Early Miocene (Ottnangian) coastal upwelling conditions along the southeastern scarp of the Bohemian Massif (Parisdorf, Lower Austria, Central Paratethys). Beiträge zur Paläontologie, 30: 387-413.

Roetzel, R., Ćorić, S., Galović, I., Rögl, F., 2007. Early Miocene (Ottnangian) coastal upwelling conditions along the southeastern scarp of the Bohemian Massif (Parisdorf, Lower Austria, Central Paratethys). Scripta Facultatis Scientiarum Naturalium Universitatis Masarykianae Brunensis, Geology, Brno, 36: $15-16$.

Rögl, F., 1996. Paragloborotalia kugleri (Bolli). An index fossil for the Paleogene/Eocene boundary. Giornale di Geologia, ser. 3 58: 151-155.

Rögl, F., Nagymarosy, A., 2004. Biostratigraphy and correlation of the Lower Miocene Michelstetten and Ernstbrunn sections in the Waschberg Unit, Austria (Upper Egerian to Eggenburgian, Central Parathetys). Courier Forschungsinstitut Senckenberg, 246 129-151.

Roth, P.H., Thierstein, H., 1972. Calcareous nannoplankton: Leg 14 of the Deep Sea Drilling Project. Initial Reports of the Deep Sea Drilling Project, 14: 421-485.

Scott, G.H., 1972. The relationship between the Miocene Foraminiferida Globorotalia miozea miozea and G. praemenardii. Micropaleontology, 18: 81-93.

Scott, G.H., 1992. Planktonic foraminiferal biostratigraphy (Altonian-Tongaporutuan Stages, Miocene) at DSDP Site 593, Challenger Plateau, Tasman Sea. New Zealand Journal of Geology and Geophysics, 35: 501-513.

Scott, H.G., Bishop, S., Burt, B.J., 1990. Guide to some Neogene Globorotalids (Foraminiferida) from New Zealand. New Zealand Geological Survey Paleontological Bulletin, 61 (Digital Edition 2013).

Scott, G.H., Nelson, C.S., Stone, H.H., 1995. Planktic foraminiferal events in early Miocene Zone N.6 and N.7 at southwest Pacific DSDP Site 593: relation with climatic changes in oxygen isotope Zone Mi1b. Marine Micropaleontology, 25: 29-45.

Sikora, W., 1970. Geology of Magura Nappe between Szymbark Ruski and Nawojowa (in Polish with English summary). Biuletyn Instytutu Geologicznego, 235: 5-121.

Sikora, W., Żytko, K., 1960. Geology of the Beskid Wysoki range South of Żywiec (in Polish with English summary). Biuletyn Instytutu Geologicznego, 141: 61-204.

Schmid, S.M., Bernoulli, D., Fügenschuh, B., Matenco, L. Schefer, S., Schuster, R., Tischler, M., Ustaszewski, K.,
2008. The Alpine-Carpathian-Dinaridic orogenic system: compilation and evolution of tectonic units. Swiss Journal of Geosciences, 101: 139-183.

Spezzaferri, S., 1991. Evolution and taxonomy of the Paragloborotalia kugleri (Bolli) lineage. Journal of Foraminiferal Research, 21: 313-318.

Stranik, Z., Hanzlikova, E., 1968. Stratigraphy of the Magura Group of nappes. In: Regional geology of Czechoslovakia (eds. M. Mahel and T. Buday): 446-480. Part II, The West Carpathians. Academia, Praha.

Subbotina, N.N., 1960. Mikrofauna oligotsenovykh i miotsenovykh otlozheniy reyona Vorotyshche (in Russian). Trudy VNIGRI, 152: 157-241.

Thierstein, H.R., Geitzenauer, K.R., Molfino, B., 1977. Global synchronity of late Quaternary coccolith datum levels: validation by oxygen isotopes. Geology, 5: 400-405.

Turner, G.M., Michalk, D.M., Morgans, H.E.G., Walbrecker, J.O., 2007. Early Miocene magnetostratigraphy and new palaeomagnetic pole position from New Zealand. Earth Planets Space, 59: 841-851.

Uhlig, V., 1890a. Geologische Spezialkarte der Österreichisch-Ungarischen Monarchie, k.k. geol. R. A., Zone 8, XXIII, Alt Lublau (Stara Lubowna) und Szczawnica, Wien (Polish edition).

Uhlig, V., 1890b. Ergebnisse geologischer Aufnahmen in den westgalizischen Karpathen. II. Der pieninische Klippenzug. Jahrbuch des Geologischen Reichanstalt, 40: 559-824.

Uhlig, V., 1903. Pieninishe Klippenzone und Tatragebirge (Excursionen in die pieninische Klippenzug und in das Tatragebirge). III c: Führer-Excursionen in Osterreich, IX Geol. Kongr., Wien.

Uhlig, V., 1907. Über die Tektonik der Karpathen. Sitzungsberichte der Kaiserischen Akademie der Wiessenschaften, mathematisch-naturwissenchaftiche Klasse, 116: 871-982.

Villa, G., Fioroni, C., Pea, L., Bohaty, S., Persico, D., 2008. Middle Eocene-late Oligocene climate variability: calcareous nannofossil response at Kerguelen Plateau, Site 748. Marine Micropaleontology, 69: 173-192.

Wade, B.S., Pearson, P.N., Berggren, W.A., Pälike, H., 2011. Review and revision of Cenozoic tropical planktonic foraminiferal biostratigraphy and calibration to the geomagnetic polarity and astronomical time scale. Earth-Science Reviews, 104: 111-142.

Watycha, L., 1963. Magura flysch of the southern part of Gorce Mts. (in Polish with English summary). Przegląd Geologiczny, 11: 371-378.

Watycha, L., 1975. Szczególowa mapa geologiczna Polski, arkusz Nowy Targ .(in Polish) Wyd. Geol., Warszawa.

Węcławik, S., 1969. Le development des depots du Paleogene dans la zone de Sacz de la nappe de Magura dans le Beskide Bas (in Polish with French summary). Geologia, 11: 7-32.

Wei, S., Wise, W., 1990. Biogeographic gradients of the middle Eocene-Oligocene calcareous nannoplankton in the South Atlantic Ocean. Palaeogeography, Palaeoclimatology, Palaeoecology, 79: 29-61.

Wei, W.G., Villa, S., Wise, W. Jr., 1992. Paleoceanographic implications of Eocene-Oligocene calcareous nannofossils from sites 711 and 748 in the Indian Ocean. Proceedings of the Ocean Drilling Program, Scientific Results, 120: 979-999.

Winter, A., Jordan, R., Roth, P., 1994. Biogeography of living Coccolithophores in ocean waters. In: Coccolithophores (eds. A. Winter and W. Siesser): 13-37. Cambridge University Press, Cambridge.

Young, J.R., 1998. Neogene. In: Calcareous Nannofossil Biostratigraphy (ed. P.R. Bown): 225-265. British Micropalaeontology Society Series.

Żytko, K., Gucik, S., Ryłko, W., Oszczypko, N., Zając, R., Garlicka, I., Nemčok, J., Eliás, M., Menčik, E., Stránik Z., 1989. Map of the Tectonic Elements of the Western Outer Carpathians and their Foreland. In: Geological Atlas of the Western Outer Carpathians and their Foreland (eds. D. Poprawa and J. Nemčok). PIG, Warszawa, GUD, Bratislava, UUG, Praha. 